\title{
KAJIAN MINAT BELANJA ONLINE PAKAIAN READY TO WEAR WANITA PLUS-SIZE
}

\author{
Krishna Wardhani M.Ds \\ Sekolah Tinggi Desain Indonesia Bandung, Jawa Barat \\ krishna.wardhani@gmail.com
}

\begin{abstract}
It is very important for a clothing brand, have a clear understanding about their target market. Clothing brands in Indonesia are starting to look at plus-size women as a potential growing market, especially for online shopping. One brand must pay attention to both products and the online shop. It is essential for a clothing brand to have their own online shop service in this day and age, especially for clothing brands that have a particular target market, such as the plus-size women. Based on previous research, the plussize women are starting to lose their interest in online shopping because of the unfulfilled expectations in designs, size precision, quality as well as the online shopping experience itself. We were using two research methods, by spreading questionnaires and direct interviews. We gathered information from 79 responders of plus-size women with clothing size starting from XXL and larger, age range between 26 to 40+ years old at $23-25$ July 2020. We used two techniques, SPSS and The Rank Spearman \& Kendall Tau method. SPSS are used to process the quantitative data to find the correlation between the clothing designs, sizes, and quality as well as the shopping experience. The Rank Spearman and Kendall Tau method are used for the correlation tests. There are several results. There is a relationship between the variables of design, size, quality, and a positive shopping experience however, quality falls into a very weak category. Body shape can be the basis for determining the design and size of the products. Several factors, such as colors, patterns, and materials, are in accordance with the desires of plus-size consumers. There is a greater chance of using the pre-order system. Optimization of websites that are used as showcases by using educational content on clothing styling and standardization of product specifications in order to create high engagement so as to foster customer trust. Further studies need to prove the efficiency of the user interface in accordance with the design recommendations.
\end{abstract}

Keywords: ready to wear; plus-size; consumer's shopping interests; online shopping

\begin{abstract}
Abstrak
Strategi yang perlu dikuasai oleh sebuah brand adalah memahami target market mereka. Terlebih apabila market tersebut adalah market yang baru tumbuh. Konsumen wanita plus-size di Indonesia adalah salah satunya. Baik produk maupun tempat berbelanja seperti toko online patut menjadi perhatian bagi sebuah brand. Bagi sebuah brand memiliki toko online adalah suatu kewajiban di masa sekarang. Semua orang sudah dapat mengoperasikan baik gawai maupun perangkat lunaknya. Market baru seperti plus-size tentu memiliki permasalahan tersendiri pada media toko online. Dari penelitian sebelumnya diketahui bahwa ketidaksesuaian produk dengan minat konsumen dapat berdampak pada kepuasan pelanggan sehingga dapat menurunkan minat belanja secara online. Dipilih variabel desain, ukuran, kualitas dan pengalaman
\end{abstract}


MODA volume 3 Nomor 2 Juli 2021

belanja untuk mengetahui minat belanja konsumen wanita plus-size. Kemudian dilihat dari teori preferensi, perilaku konsumen, dan penggunaan user interface. Metode yang dipakai adalah mix method menggunakan kuesioner dan wawancara. Responden dibatasi pada wanita berusia 18 hingga lebih dari 40 tahun dan memiliki ukuran pakaian mulai dari XXL. Jumlah data responden sebanyak 79 orang terhitung dari tanggal 23 hingga 25 Juli 2020. Narasumber sebanyak 3 orang, mewakili usia terbanyak pada kuesioner yaitu di atas 40 tahun dan usia 26 hingga 35 tahun. Data kuantitatif kemudian diolah menggunakan SPSS untuk mencari korelasi antara variabel desain, ukuran, kualitas terhadap pengalaman belanja. Uji korelasi yang dipakai adalah Rank Spearman dan Kendall Tau. Hasil dari penelitian ini yaitu adanya hubungan antara variabel desain, ukuran, kualitas, dengan pengalaman belanja yang positif namun masuk ke dalam kategori cukup dan sangat lemah pada ukuran. Bentuk tubuh dapat menjadi dasar penentuan desain dan ukuran pada produk. Beberapa faktor seperti warna, motif, dan bahan sudah sesuai dengan keinginan konsumen plus-size. Adanya peluang lebih besar bila menggunakan sistem pre-order. Optimalisasi website yang dijadikan showcase dengan menggunakan konten edukasi styling pakaian dan adanya standarisasi pada spesifikasi produk agar terciptanya engagement yang tinggi sehingga menumbuhkan kepercayaan pelanggan. Studi selanjutnya perlu dibuktikan efisiensi pada user interface yang sesuai dengan rekomendasi desain.

Kata kunci: pakaian ready to wear; plus-size; minat belanja konsumen; belanja online 
Wardhani

Kajian Minat Belanja Online Pakaian Ready To Wear Wanita Plus-Size

\section{PENDAHULUAN}

Penderita obesitas lebih banyak menyerang wanita ketimbang pria berdasarkan Riset Kesehatan Dasar (Riskesdas). Pada tahun 2013 prevalensi nasional obesitas orang dewasa (usia lebih dari 18 tahun) adalah wanita sebesar 32,9\% dan pria 19,7\% (Iskandar, I.A.W \& Nursari, F, 2017). WHO mencatat terdapat 300 juta wanita yang mengalami obesitas, atau sekitar 10\% populasi dunia. Selain orang dewasa, sejak tahun 1970 hingga kini, tercatat obesitas menyerang anak usia 2-5 tahun dan 12-19 tahun meningkat hingga dua kali lipat. Prosentase obesitas pada anak usia 6-15 tahun pada tahun 1990 meningkat dari 5\% menjadi 16\% pada tahun 2001 (Sartika, $R, 2011)$. Hasil Riskesdas 2007-2018 di Indonesia angka obesitas menunjukkan kecenderungan meningkat yaitu 10.5\% (2007), 14,8\% (2013) dan $21,8 \%$ (2018). Untuk Provinsi Jawa Barat sendiri, berdasarkan Riskesdas tahun 2018 prevalensi obesitas menempati peringkat ke 14 dari 34 Provinsi di Indonesia 15,2\% (2013) menjadi 23\% (2018).

Bertambahnya kelompok orang dengan obesitas, menyebabkan adanya kebutuhan baru yang harus dipenuhi dalam bidang industri pakaian yang disebut sebagai plus-size. Di Amerika misalnya, ukuran tubuh perempuan saat ini adalah lebih besar daripada beberapa dekade sebelumnya. Sehingga kategori plus-size menjadi market yang cepat pertumbuhannya dengan lebih dari dua atau tiga perempuan yang masuk dalam klasifikasi kelebihan berat badan atau obesitas (Odgen, Caroll, Kit \& Flegal, 2014).

Plus-size menurut Mintel adalah produksi garmen dengan ukuran 18 ke atas (Haswell, N.S,2010). Meskipun demikian banyak jurnal lain yang mengkategorikan plus-size sebagai ukuran garmen mulai dari size 14 atau 16 ke atas. Size garmen yang dimaksud adalah angka standar yang telah ditentukan oleh peritel agar konsumen dengan mudah menemukan ukuran pakaian mereka (Colls, 2004). Kata plus-size sendiri tidak semata-mata merefleksikan kesehatan serta kekurangan seseorang (Young, 2005). Meskipun demikian kata plus-size erat kaitannya dengan obesitas dan beberapa penyakit seperti hipertensi, kanker, dan kardiovaskular (Hu, 2003).

Beberapa brand di Amerika dan Eropa mungkin sudah banyak yang mengeluarkan lini plus size, namun ritel yang masuk ke Indonesia tidak mengimpor lini plus-size mereka. Hal ini sebetulnya ada pada tangan merchandiser di Indonesia. Merekalah yang menentukan artikel pakaian seperti apa yang cocok untuk masuk ke pasar Indonesia. Kemunculan brand My Size menjadi salah satu pionir brand plus-size di saat yang lain tidak melihat adanya potensi. My Size menjadi brand dengan konsep penyediaan pakaian plus-size dan membuka gerai di mallmall di Jakarta. Kini My Size sudah membuka gerai sebanyak 12 toko yang tersebar di berbagai kota di Indonesia. Mengikuti jejak My Size, muncul brand plus-size lainnya seperti Pofeleve, Bssar, dan Bigissimo. Munculnya brand-brand 
tersebut seiring dengan semakin lumrahnya penjualan pakaian secara online salah satunya e-commerce. Konsumenpun semakin terbiasa akan pembelian barang melalui gawai. Selain keempat brand tadi yang memilih penjualan pada platform Instagram, brand e-commerce yang cukup besar seperti Zalora dan Berrybenka kini juga menyediakan lini plus-size pada pilihan produk pakaian wanita mereka.

Data yang dirilis oleh Menkominfo menunjukkan terdapat nilai transaksi sebesar Rp.130 trilyun pada e-commerce tahun 2013, dengan angka pengguna internet sebesar 82 juta orang (Sidharta, Suzanto, 2015). Lembaga riset ICD menyebutkan bahwa perkiraan Indonesia menjadi salah satu negara dengan pertumbuhan e-commerce terbesar di Asia-Pasific. Dilansir dari Statista.com, pendapatan dari pasar e-commerce di Indonesia mencapai US $\$ 26,922 \mathrm{~m}$ di tahun 2020 dengan pertumbuhan $16.9 \%$ pertahunnya. Pasar terbesar adalah segmen fesyen dengan pendapatan hingga US\$6,771m. Rentang usia pengguna e-commerce adalah 18-24 tahun sebanyak 34.8\%, 25-34 tahun sebanyak 40.7\%, dan 35-44 tahun sebanyak 24.5\% (Statista Global Consumer Survey, 2019).

Jakarta dan Jawa Barat dikenal sebagai pusat trend fesyen Indonesia karena pusat perbelanjaan dan ekonomi masih belum merata ke propinsi atau pulau lain di Indonesia. Sehingga masyarakat di Jakarta dan di Jawa Barat cenderung lebih dulu terpapar trend fesyen terbaru baru kemudian wilayah lain mengikuti. Banyak merk internasional yang memiliki lini plus-size di luar Indonesia. Namun di Indonesia merk yang baru memasukkan lini plus-sizenya adalah $\mathrm{H} \& \mathrm{M}$ dan lini tersebut hanya tersedia di cabang mall Grand Indonesia. Selain H\&M ada pula Marks \& Spencer yang sudah lebih dulu memiliki range ukuran yang sangat besar tanpa embel-embel plus-size.

Untuk mendirikan sebuah bisnis, sebuah brand harus memiliki strategi yang praktis agar tepat sasaran dan menghemat waktu. Dengan adanya strategi ini, diharapkan sebuah brand dapat berkembang. Strategi konsumen dapat didapati dengan melakukan pendekatan melalui preferensi. Preferensi seseorang dalam membeli satu benda didasari oleh berbagai macam faktor seperti kebudayaan, sosial, pribadi dan psikologis (Kotler, 2000). Dengan memahami preferensi konsumen plus-size diharapkan sebuah brand khususnya di Jawa Barat dapat membaca perilaku konsumen dalam melakukan keputusan pembelian dalam hal ini pakaian ready to wear.

Pada penelitian yang dilakukan oleh Meng Wang (2007) variabel yang diteliti adalah faktor keragaman dan kualitas untuk mencari atribut yang penting untuk konsumen plus-size di Amerika. Selfia Sentana (2019) menggunakan variabel seberiti, lingkungan, brand identity, dan citra tubuh dalam penelitiannya yang membahas mengenai faktor yang mempengaruhi body image terhadap niat beli produk fesyen. Sedangkan 
Seram \& Kumarasiri (2020) menggunakan variabel kualitas, fit, tipe kain, harga, desain, affordable, durability, trendy, unik dan kenyamanan untuk brand plus-size di Sri Lanka. Di Indonesia sendiri masih jarang penelitian yang membahas hal ini maka dari penelitian sebelumnya peneliti membagi variabel menjadi desain, ukuran, kualitas, dan pengalaman belanja untuk mengukur minat belanja online konsumen plus-size di Indonesia.

\section{TINJAUAN PUSTAKA}

Terdapat tiga penelitian terdahulu yang mengkaji mengenai niat pembelanjaan konsumen. Hasil penelitian kemudian dijadikan dasar penentuan variabel-variabel yang akan dipakai dalam penelitian ini. Pertama dilakukan oleh Meng Wang (2007) yang menggunakan variabel kepercayaan diri, konsep citra diri, harga, keragaman produk, kualitas produk, dan bentuk visual toko. Kedua ada Selfia Sentana (2019) yang menggunakan variabel kepercayaan diri, preferensi pribadi, selebriti, keluarga dan teman, niat beli pasif dan aktif. Terakhir dari Niromi Seram dan Kethmini Kumarasiri (2020) yang menggunakan variabel kualitas, fit, tipe kain, harga, dan fashionability. Penelitian terdahulu ini yang kemudian menjadi dasar penentuan variabel penelitian menjadi desain, ukuran, kualitas, dan pengalaman belanja.

\section{Bentuk Tubuh Wanita}

Laki-laki dan wanita diberikan bentuk fisik yang berbeda sesuai dengan peran masing-masing.
Pada tubuh wanita peran hormon estrogen yang dikeluarkan oleh ovarium memberikan efek yang signifikan terhadap bentuk tubuh wanita seperti pembentukan dada dan pinggul pada saat masuk masa pubertas (Seram. N, Kumarasiri K, 2020). Hormon estrogen juga berperan dalam pendistribusian lemak pada tubuh wanita. Proporsi bentuk tubuh ini yang menjadi acuan pengukuran, yaitu lingkar dada, pinggang, dan pinggul (Gribbin, 2014). Tiga area ini dikenal dengan sebutan "body inflection points". Body inflection points adalah sebuah titik kurva dimana perubahan arah kelengkungan terjadi. Jarak antara titik infleksi ditentukan oleh tinggi seseorang, sehingga semakin tinggi seseorang maka akan mempengaruhi proporsi dari keseluruhan tubuh. Meskipun demikian rasio dari pinggang dan pinggul lebih stabil dan lebih terukur sehingga secara signifikan lebih berkorelasi dengan distribusi lemak (Singh, 2006).

\section{Klasifikasi Bentuk Tubuh dalam Fashion}

Faktor pembeda dari tipe bentuk tubuh dalam jurnal oleh Hidayanti dkk (2018) dilihat dari perbedaan ukuran dada, pinggang, pinggul seperti berikut:

a. Apel: Bagian dada dan pinggul bulat dengan tidak adanya bentuk pada pinggang

b. Hourglass: Bagian dada dan pinggul bulat dengan adanya bentuk pada pinggang

c. Inverted triangle: Bagian bahu lebar dengan pinggul yang lebih kecil

d. Rectangle atau straight: Bagian bahu, dada, 
dan pinggul sama besar dengan sedikit bentuk pada pinggang

e. Pir: Bagian pinggul lebih besar dari dada, bahu, dan pinggang

Dalam jurnal Seram \& Kumarasiri (2020) disebutkan bahwa bentuk tubuh terbanyak di Sri Lanka adalah pir, hourglass, dan apel. Sri Lanka adalah negara yang terletak di Asia Tenggara dengan ras yang beragam termasuk salah satunya adalah Malays. Ras Malays berasal dari Jawa, Indonesia (Perera, 1974). Maka bentuk tubuh terbanyak ini juga bisa diaplikasikan pada konsumen di Indonesia.

\section{Plus-size}

Untuk menentukan seseorang masuk ke dalam kategori plus-size atau tidak, diperlukan kajian mengenai terminologi plus-size. Beberapa penjelasan terminologi plus-size yang diambil dari beberapa jurnal:

a. Hanna Limatius (2018): Pemakaian kata "fat", "curvy" dan "plus size" untuk menunjukkan sebuah konotasi: "fat" dianggap kata yang merugikan, "curvy" dianggap lebih positif, dan "plus size" dianggap netral. Hasil menunjukkan kebanyakan blogger memilih "fat" dan "plus size" ketimbang "curvy". Meskipun demikian blogger (plussize) yang memakai kata "fat" adalah para aktivis yang fokus pada penerimaan bentuk tubuh (self-empowerment), sedangkan yang mengusung topik fesyen lebih memilih menggunakan kata "plus size". b. Natasha Sian Haswell (2010): Plus-size menurut Mintel adalah produksi garmen dengan ukuran 18 ke atas (Mintel, 2006). Meskipun demikian secara general terminologi kata plus-size dipakai untuk mendeskripsikan seseorang yang memakai ukuran 16 atau lebih.

c. Usha Chowdhary \& Nadine V. Beale (1988): Plus-size dikategorikan sebagai pemakai pakaian ritel (ready to wear) ukuran $16 \mathrm{ke}$ atas. Wanita plus-size banyak menemukan diskriminasi, terutama pada departemen store yang menjual pakaian plus-size dengan gaya terbatas. Meskipun manufaktur dan ritel sudah mencoba untuk merespon kebutuhan dari market 'large-size', pendekatan yang mereka lakukan lebih kepada strategi marketing ketimbang perspektif konsumen.

d. Deborah A. Christel (2017): Dalam istilah fesyen, kata plus-size merujuk kepada pakaian wanita ukuran 14 dan seterusnya (Plunkett, 2015).

Dari keempat jurnal di atas, kata plus-size dipakai untuk pakaian ready to wear yang diproduksi oleh manufaktur untuk dipakai oleh orang dengan ukuran pakaian dimulai dari 14 atau XXL. Ini menjadi dasar penelitian untuk membatasi responden penelitian.

\section{Brand plus-size di Indonesia}

Brand plus-size di Indonesia bermunculan seiring dengan pertumbuhan konsumennya. 
Berikut adalah tinjauan dari brand online plussize di Indonesia yang dipilih dari segi tingkat kepopulerannya. Menurut Surachman (2008) kesadaran akan sebuah brand (brand awareness) merupakan kekuatan sebuah brand untuk dapat diingat oleh calon konsumen bahwa brand tersebut merupakan bagian dari kategori tertentu.

\section{A. My Size}

My size termasuk pionir dalam industri pakaian plus-size. Berdiri sejak tahun 2003, My Size yang sebelumnya beroperasi dengan membuka toko offline di mall kini ikut menjual produk mereka melalui toko online dengan website mysizestore.com.

B. Bigissimo

Berdiri sejak tahun 2016, Bigissimo adalah brand fesyen yang memproduksi pakaian untuk wanita plus-size. Fokus mereka adalah kepada pemberdayaan wanita dan isu-isu positif mengenai tubuh. Mereka memproduksi pakaian yang chic dan nyaman untuk wanita plus-size sehingga mereka dapat mengekspresikan diri melalui mode.

\section{Pofeleve}

Berdiri pada tahun 2014, Pofeleve adalah singkatan dari para pendirinya yaitu Poppy Hanadhy, Fe Utomo, Helen Bellina, dan Holy Veronica. Pofeleve mengeluarkan baju untuk wanita reguler dan plus-size dengan visi bahwa kata "keren" dan "cantik" dapat diajukan kepada seluruh wanita tanpa melihat ukuran bentuk tubuhnya.

D. Bodybigsize

Bodybigsize adalah brand lokal yang menjual pakaian khusus plus-size dengan ukuran dari XL hingga 8XL. Pakaian yang dijual bermacam-macam seperti dress, blus, hijab, sampai dengan lingerie.

\section{Belanja Online}

Sikap konsumen sangat mempengaruhi minat dalam berbelanja online. Sikap adalah rasa suka atau tidak suka bagi orang, kelompok, ide, dan situasi (Mowen \& Minor, 2001). Selain sikap terdapat satu hal yang sangat mempengaruhi belanja online yaitu kepercayaan atau trust. Menurut Mowen \& Minor (2001) kepercayaan adalah pengetahuan yang dimiliki oleh konsumen dan kesimpulan yang yang telah terbentuk mengenai objek, atribut, dan manfaat dari satu barang atau jasa. Ketika rasa kepercayaan itu telah terbentuk, maka konsumen akan lebih berani untuk melakukan transaksi secara berkelanjutan dalam ranah online (Mahardika \& Saino, 2014). Mahardika \& Saino (2014) mengatakan bahwa salah satu cara untuk membangun kepercayaan bagi konsumen adalah dengan memahami perasaan konsumen.

Pada toko online, kepercayaan yang terbentuk adalah antara konsumen dan website, bukan dengan penyedia barang (Lim dkk, 2014). Maka kepercayaan menjadi penting karena konsumen 
dan retailer tidak dapat bertemu secara fisik dan berkomunikasi (Karnadjadja dkk, 2017). Ashur (2016) dalam penelitiannya mengatakan bahwa persepsi risiko yang dirasakan konsumen juga mempengaruhi faktor kepercayaan tersebut. Semakin rendah risiko maka semakin tinggi kepercayaan konsumen terhadap online shop (Karnadjaja dkk, 2017).

Dengan mengetahui minat belanja pada konsumen khusus seperti konsumen plussize menjadi salah satu cara untuk memahami perasaan mereka dalam memilih pakaian ready to wear secara online. Pemahaman tersebut dapat melalui pendekatan faktor desain, ukuran, kualitas, dan pengalaman belanja.

\section{Teori Preferensi}

Menurut Brown (1992), preferensi personal terhadap pakaian yang cocok dipengaruhi oleh trend fesyen saat pembelian berlangsung, budaya, umur, jenis kelamin, bentuk tubuh, dan gaya hidup (Alexander, 2005). Sedangkan preferensi menurut Kotler (2000) adalah kecenderungan kepada satu barang atau jasa yang dikonsumsi.

Faktor-faktor yang mempengaruhi preferensi menurut Nugroho J. Setiadi (2019):

a. Faktor Kebudayaan: faktor mendasar yang menentukan keinginan seseorang. Dalam kebudayaan juga yang membentuk preferensi seseorang adalah kelas sosial mereka

b. Faktor Sosial: faktor referensi kelompok, keluarga, dan peran atau status seseorang dalam masyarakat

c. Faktor Pribadi: umur, pekerjaan, gaya hidup, serta konsep diri dari seseorang

d. Faktor Psikologis: motivasi, persepsi, proses belajar, dan kepercayaan atau sikap

Preferensi konsumen dapat terbentuk bila konsumen merasa puas akan barang atau jasa yang mereka dapat. Dalam menentukan kepuasan konsumen, sebuah persepsi terhadap kualitas barang atau jasa dari pelanggan atau konsumen harus sesuai dengan yang diharapkan. Apabila hal tersebut sudah sesuai maka dapat dikatakan baik dan sebaliknya (Sidharta, 2015). Beberapa faktor utama yang perlu diperhatikan untuk memenuhi harapan dari preferensi konsumen yaitu diantaranya (1) kualitas produk, (2) kualitas layanan, (3) emosional, (4) harga, dan (5) biaya. Faktor ini akan mempengaruhi kepuasan dari konsumen dan mereka akan kembali membeli produk yang sama apabila faktor tersebut sesuai dengan yang diharapkan (Lupiyaodi, 2001).

\section{Teori Customer Behavior}

Pada jurnal Chandrasekar (2015) mengenai perilaku belanja konsumen disebutkan bahwa perilaku konsumen adalah sebuah studi mengenai satu individu, group, atau organisasi dan proses yang mereka gunakan untuk memilih, memperoleh, dan menentukan sebuah 
produk, jasa, pengalaman, dan ide untuk mencapai kepuasan dan bagaimana efeknya kepada konsumen dan masyarakat. Perilaku konsumsi dari satu individu atau rumah tangga dalam membeli produk untuk konsumsi pribadi (Chandrasekar, K, Madhavan, M. 2015). Perilaku konsumen memperlihatkan bagaimana seorang individu memakai atau membuang apa yang ditawarkan oleh sebuah brand. Baik barang maupun jasa dapat didapatkan melalui proses berbelanja, namun bisa juga melalui proses barter atau pertukaran, penyewaan, dan peminjaman.

Dalam bukunya, Sumarwan (2011) menjelaskan beberapa faktor yang menjadi penentu konsumen dalam berperilaku dari segi demografis. Hal tersebut dibagi menjadi:

1. Usia
a. Konsumen yang berbeda usia akan mengkonsumsi produk dan jasa yang berbeda
b. Perbedaan usia mempengaruhi perbedaan selera terhadap suatu merk
c. Usia bisa dijadikan dasar penentuan segmentasi dari segi pemasaran produk
d. Penentuan keragaman produk bisa didasari oleh faktor usia

2. Pendidikan dan pekerjaan

a. Pendidikan mempengaruhi pekerjaan seorang konsumen sehingga ber- pengaruh pula terhadap pendapatannya

b. Pendidikan dan pendapatan dapat mempengaruhi proses keputusan dan pola konsumsi konsumen

c. Pendidikan akan mempengaruhi nilai, cara pandang, persepsi, dan cara berpikir seseorang

d. Pendidikan yang lebih tinggi akan berpengaruh dalam memproses suatu informasi sehingga berakibat dalam pemilihan produk dan merk

e. Pemahaman produsen akan kebutuhan konsumen dengan tingkat Pendidikan tertentu diperlukan untuk dapat memenuhi kebutuhan konsumen

3. Geografis

a. Pola konsumsi seseorang bisa dipengaruhi oleh dimana ia tinggal

b. Kemudahan mengakses barang dan jasa bisa ditentukan oleh letak geografis

c. Indonesia terdiri dari kepulauan dan jumlah penduduk yang kurang lebih 218 juta dan tersebar di seluruh wilayah Indonesia (Bps sensus 2005)

4. Kelas sosial

a. Menurut Schiffman \& Kanuk (2010)

Pembagian anggota masyarakat ke dalam hirarki status yang berbeda. Sehingga anggota masing-masing kelas yang relative memiliki status 
yang sama dan anggota dari semua kelas lainnya memiliki status yang lebih baik atau kurang.

b. Menurut Engel, Blackwell, \& Miniard (1995)

Suatu kelompok homogen dengan individual atau keluarga yang berbagi nilai, gaya hidup, ketertarikan yang sama serta perilaku yang dapat dikategorikan. Hal ini dapat dikelompokkan berdasarkan kesamaan perilaku dalam tingkat ekonomi di masyarakat.

c. Menurut Peter \& Olson (2010) Mengacu kepada hirarki status nasional dimana kelompok dan individu dibedakan dalam hal harga diri dan prestis.

Dengan mengetahui perilaku konsumen, sebuah manufaktur atau brand dapat memilih strategi terbaik yang tepat sasaran. Identifikasi perilaku konsumen juga dapat mengurangi waktu mereka dalam berbelanja sekaligus meningkatkan jumlah barang yang akan dibelanjakan (Nkambule, 2010). Maka dari itu sangat penting untuk mengerti problem yang dihadapi oleh konsumen plus-size.

\section{User Interface}

User interface adalah tampilan muka pada perangkat lunak yang biasa digunakan pada gadget. Menurut Lennartz dan Friedman (2009), UI adalah desain tampilan antarmuka yang harus sesuai dengan penggunanya. Bukan hanya sekedar penggunaan warna dan tombol saja namun kepada siapa desain tampilan ini digunakan. Terdapat elemen-elemen yang menentukan kualitas dari UI yaitu jelas, ringkas, familiar, responsif, konsisten, estetik, dan efisien (Lennartz \& Friedman, 2009)

Prinsip-prinsip dalam perancangan UI menurut Blair-early dan Zender (2008) adalah sebagai berikut:

1. Cara memulai yang jelas

Pada saat pengguna memulai aplikasi, ikon dan menu jelas akan menuju kemana dan efek yang ditimbulkan apa.

2. Clear reverse

Pada saat digunakan, terdapat tombol untuk kembali ke menu sebelumnya atau keluar dari aplikasi

3. Consistent logic

Menggunakan cara kerja yang konsisten dalam hal fungsi ikon dan menu sehingga memudahkan pengguna

4. Familier

Mencari tahu UI yang sering digunakan oleh masyarakat kebanyakan, sehingga pada saat diluncurkan sudah dapat digunakan dengan mudah bagi mereka

5. Feedback

Terdapat fitur feedback agar aplikasi terus dapat diperbaiki. Bagi konsumen dapat dibuat fitur reward.

6. Menu bantuan

Terdapat menu bantuan yang mudah 
ditemukan oleh pengguna.

7. Konten

Inti dari sebuah UI adalah isi kontennya. Seluruhnya harus sejalan dengan konten apa yang akan diusung dalam pembuatannya maka harus jelas dan terpenuhi.

Dengan pendekatan user interface, kebutuhan konsumen plus-size dapat segera diaplikasikan ke dalam sebuah aplikasi mobile. Kemudahan dan interaksi menjadi faktor yang penting disini.

\section{METODE}

Metode kuantitatif dan kualitatif digunakan untuk mencapai tujuan penelitian ini yaitu mengkonfirmasi apakah faktor desain, ukuran, kualitas, dan pengalaman berbelanja berpengaruh terhadap minat belanja online pakaian ready to wear wanita plus-size. Metode kuantitatif dilakukan dengan penyebaran kuesioner karena dapat disebar lewat berbagai macam media elektronik di masa pandemi. Kemudian metode kualitatif diperlukan untuk memperkuat data penelitian.

\section{Metode Kuantitatif}

Teknik sampling yang dipakai dalam penelitian ini adalah non-probability sampling yaitu peneliti tidak memberikan peluang yang sama bagi setiap anggota populasi untuk dipilih menjadi anggota sampel (Sugiyono, 2019). Lebih spesifik lagi pengambilan sampel menggunakan teknik quota sampling yaitu penentuan sampel dari populasi yang memiliki ciri-ciri tertentu sampai jumlah kuota yang diinginkan dapat mewakili keseluruhan populasi (Sugiyono, 2019). Berdasarkan hal tersebut, peneliti memiliki batasan populasi dan karena jumlah dari populasi wanita plus-size di Indonesia tak terhingga maka peneliti menggunakan teknik quota sampling. Penyebaran kuesioner dilakukan secara online menggunakan google form sejak tanggal 23 Juli hingga 25 Juli 2020. Responden yang dicari berdasarkan kriteria wanita berusia 18-50 tahun dengan ukuran pakaian XXL ke atas. Kuesioner dirancang berdasarkan penelitian terdahulu dengan menggunakan skala likert 5 poin dari 1 hingga 5.

Sampel adalah bagian dari jumlah atau karakteristik yang dimiliki oleh populasi. Pengambilan sampel boleh dipakai oleh peneliti apabila populasi yang diteliti terlalu besar, terbatasnya waktu, dan terbatasnya dana. Dengan syarat yang akan dijadikan sampel harus betul-betul mewakili populasi yang diinginkan peneliti (Sugiyono, 2019).

Dengan menggunakan kalkulator slovin, didapatkan angka sebesar 74 untuk jumlah sampel minimal penelitian dari jumlah populasi 270.600.000 penduduk di Indonesia pada tahun 2019. Variabel yang diteliti adalah demografi, desain $\left(X_{1}\right)$, ukuran $\left(X_{2}\right)$, kualitas $\left(X_{3}\right)$, dan pengalaman belanja $(Y)$ sehingga mendapatkan hasil minat belanja konsumen plus-size. Hubungan variabel tersebut digambarkan dalam gambar l.1. 


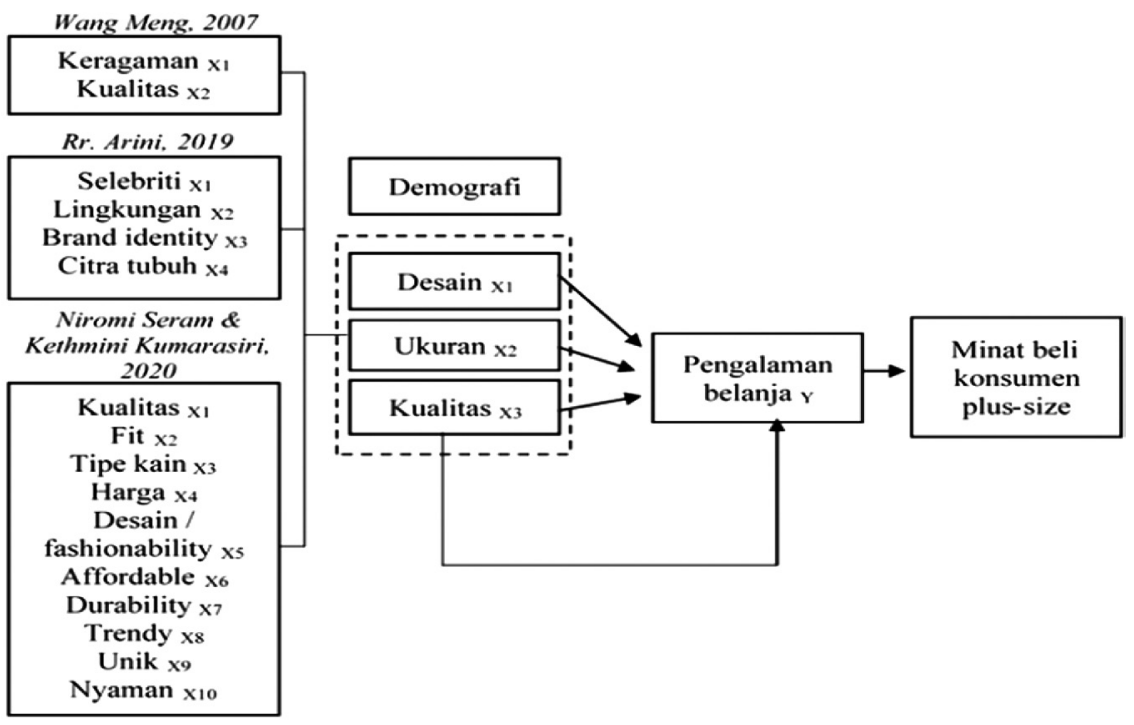

Gambar I.1 Hubungan antar variabel penelitian. Wardhani (2021)

Setelah data dikumpulkan kemudian diolah menggunakan SPSS (27.0) dengan melakukan pengujian validitas, reliabilitas, normalitas, dan linearitas terlebih dahulu. Uji validitas menunjukkan adanya 11 butir dari 39 pertanyaan dinyatakan tidak valid dan digugurkan, selanjutnya uji reliabilitas menunjukkan data reliabel setelah 11 pertanyaan tadi dihilangkan.

Uji normalitas menunjukkan data berdistribusi normal, namun pada uji linearitas (tabel I.1) menunjukkan variabel ukuran tidak linear. Maka dari itu uji korelasi yang digunakan sifatnya non parametris menggunakan Rank Spearman dan Kendall Tau.

Tabel I. 1 Hasil uji linearitas. Data olahan Wardhani (2021)

\begin{tabular}{|l|l|c|c|}
\hline No & Variabel & Linearity & Status \\
\hline 1 & Desain & 0.032 & Valid \\
\hline 2 & Ukuran & 0.123 & Non Valid \\
\hline 3 & Kulaitas & 0.038 & Valid \\
\hline
\end{tabular}

Uji non parametrik rank Spearman dan Kendall Tau dipakai untuk memperlihatkan apakah terdapat korelasi antara variabel $\mathrm{x}$ dan $\mathrm{y}$ dan seberapa kuat nilai korelasi antar variabel tersebut.

\section{Uji Rank Spearman}

Ketentuan yang berlaku untuk uji rank Spearman adalah angka significance-nya apabila $<0,05$ maka ada hubungan korelasi antara variabel independen dengan variabel dependen.

Tabel I. 2 Hasil uji Rank Spearman. Data olahan Wardhani (2021)

\begin{tabular}{|c|l|c|c|c|}
\hline No & Variabel & $\begin{array}{c}\text { Correlation } \\
\text { Coefficient }\end{array}$ & Status & Keterangan \\
\hline 1 & Desain & 0,392 & Diterima & Cukup \\
\hline 2 & Ukuran & 0,405 & Diterima & Cukup \\
\hline 3 & Kualitas & 0,329 & Diterima & Cukup \\
\hline
\end{tabular}

Pada tabel I.2, hubungan antara faktor desain, ukuran dan kualitas ketiganya memiliki angka 
$<0.05$ sehingga dapat disimpulkan bahwa faktor desain, ukuran, dan kualitas berpengaruh terhadap faktor pengalaman belanja online konsumen plus-size.

\section{Uji Kendall Tau}

Pengujian non-parametrik juga dapat dilakukan menggunakan uji Kendall Tau. Tidak ada syarat apapun untuk pengujiannya sehingga data tidak perlu berdistribusi normal dan linear. Data dianggap mempunyai korelasi apabila nilai signifikansinya < 0.05 dan besarnya hubungan korelasi dapat kita lihat dari nilai correlation coefficientnya.

Tabel I. 3 Hasil uji Kendall Tau.

Data olahan Wardhani (2021)

\begin{tabular}{|l|l|c|c|c|c|}
\hline No & Variabel & $\begin{array}{c}\text { Sig } \\
\text { (2-tailed) }\end{array}$ & $\begin{array}{c}\text { Correlation } \\
\text { Coefficient }\end{array}$ & Status & Ket \\
\hline 1 & Desain & $<0,001$ & 0,289 & Diterima & Cukup \\
\hline 2 & Ukuran & $<0,001$ & 0,302 & Diterima & Cukup \\
\hline 3 & Kualitas & 0,004 & 0,241 & Diterima & $\begin{array}{l}\text { Sangat } \\
\text { lemah }\end{array}$ \\
\hline
\end{tabular}

Bila diperhatikan lebih lanjut pada keterangan hubungan yang terjadi pada variabel $\mathrm{x}$ dan $\mathrm{y}$ masuk ke dalam kategori cukup dan variabel kualitas pada uji korelasi Kendall Tau terlihat masuk ke dalam kategori sangat lemah.

\section{Demografi Responden}

Kuesioner yang telah disebar dalam 3 hari, terhitung sebanyak 79 responden yang sesuai dengan kriteria yang dibutuhkan. Hasil kuesioner berupa data jawaban pertanyaan demografis, desain, ukuran, kualitas, dan pengalaman belanja. Demografi dari penelitian ini seperti yang dapat dilihat pada tabel I.4.
Tabel I. 4 Data demografis responden.

Data olahan Wardhani (2021)

\begin{tabular}{|c|c|c|c|}
\hline No & Data Demografis & Ket & \\
\hline \multirow[t]{2}{*}{1} & Usia & $26-35$ tahun & $30,4 \%$ \\
\hline & & $>40$ tahun & $44,3 \%$ \\
\hline \multirow[t]{2}{*}{2} & Pekerjaan & IRT & $26,6 \%$ \\
\hline & Pegawai & swasta & $25,3 \%$ \\
\hline \multirow[t]{3}{*}{3} & Domisili & Bandung & $30,4 \%$ \\
\hline & & Bekasi & $24,1 \%$ \\
\hline & & Depok & $16,5 \%$ \\
\hline \multirow[t]{3}{*}{4} & Penghasilan & & \\
\hline & bulanan & Rp.1 - 5juta & $31,6 \%$ \\
\hline & & Rp.10 - 15juta & $19 \%$ \\
\hline \multirow[t]{4}{*}{5} & Berat & & \\
\hline & badan & $66-85 \mathrm{~kg}$ & $51,9 \%$ \\
\hline & & $86-100 \mathrm{~kg}$ & $29,1 \%$ \\
\hline & & $101-120 \mathrm{~kg}$ & $15,2 \%$ \\
\hline \multirow[t]{3}{*}{6} & Ukuran & & \\
\hline & pakaian & $X X L$ & $74,7 \%$ \\
\hline & & $3 X L$ & $15,2 \%$ \\
\hline \multirow[t]{3}{*}{7} & Kategori pakaian & & \\
\hline & yang sering dibeli & Atasan & $60,8 \%$ \\
\hline & & Bawahan & $30,2 \%$ \\
\hline \multirow[t]{2}{*}{8} & Media pembayaran & Transfer bank & $52 \%$ \\
\hline & & Kartu kredit/debit & $15 \%$ \\
\hline \multirow[t]{2}{*}{9} & Cara mendapat & & \\
\hline & info & Media sosial & $23 \%$ \\
\hline
\end{tabular}

Dari tabel 1.4 dapat dilihat bahwa responden untuk penelitian ini adalah berusia lebih dari 40 tahun dan 26 sampai 35 tahun. Pekerjaan Ibu rumah tangga dan pegawai swasta. Berdomisili di Bandung, Bekasi, dan Depok. Penghasilan di angka satu juta hingga lima juta rupiah. Berat badan terbesar adalah antara 66 sampai 85 $\mathrm{kg}$ dengan ukuran pakaian terbanyak di XXL. Pembelian terbanyak adalah untuk atasan, media 
pembayaran transfer bank, dan mendapatkan info dari sosial media yang mereka pakai.

\section{Hasil kuesioner}

Tabel I. 5 Hasil data kuesioner penelitian. Data olahan Wardhani (2021)

\begin{tabular}{|c|c|c|}
\hline $\begin{array}{l}\text { Variabel } \\
\text { Desain }\end{array}$ & Ststus & Keterangan \\
\hline Trend & Netral & \\
\hline Basic & Sangat setuju & \\
\hline Pola unik & Netral & $\begin{array}{l}\text { Berbeda } \\
\text { satu suara } \\
\text { dengan } \\
\text { sangat tidak } \\
\text { setuju }\end{array}$ \\
\hline Motif besar & Netral & $\begin{array}{l}\text { Berbeda } \\
\text { satu suara } \\
\text { dengan } \\
\text { sangat tidak } \\
\text { setuju }\end{array}$ \\
\hline Warna mencolok & Netral & $\begin{array}{l}\text { Berbeda } \\
\text { satu suara } \\
\text { dengan } \\
\text { sangat tidak } \\
\text { setuju }\end{array}$ \\
\hline \multicolumn{3}{|l|}{ Ukuran } \\
\hline Pinggang sempit & Sangat setuju & \\
\hline Lengan baju sempit & Sangat setuju & \\
\hline Pinggang celana sempit & Sangat setuju & $\begin{array}{l}\text { Berbeda } \\
\text { satu suara } \\
\text { dengan netral }\end{array}$ \\
\hline Pinggul celana sempit & Sangat setuju & \\
\hline Range ukuran besar & Sangat setuju & \\
\hline Ukuran fix & Sangat setuju & \\
\hline \multicolumn{3}{|l|}{ Kualitas } \\
\hline $\begin{array}{l}\text { Kualitas tinggi } \\
\text { harga mahal }\end{array}$ & Sangat tidak setuju & $\begin{array}{l}\text { Berbeda satu } \\
\text { suara dengan } \\
\text { netral }\end{array}$ \\
\hline Variasi bahan & Netral & \\
\hline $\begin{array}{l}\text { Kesesuaian foto } \\
\text { dengan barang asli }\end{array}$ & Netral & \\
\hline \multicolumn{3}{|l|}{ Pengalaman Belanja } \\
\hline Tidak terpaku satu brand & Sangat setuju & \\
\hline $\begin{array}{l}\text { Kemudahan pembelian } \\
\text { online }\end{array}$ & Netral & \\
\hline Peran influencer & Netral & \\
\hline $\begin{array}{l}\text { Meningkatkan } \\
\text { kepercayaan diri }\end{array}$ & Sangat setuju & \\
\hline
\end{tabular}

Dari tabel 1.5 dapat disimpulkan bahwa minat konsumen plus-size adalah menggunakan pakaian basic dengan pola standar. Motif dan warna lebih banyakyang menyukai kecil dantidakmencolok. Dari segi ukuran banyak yang mengalami kesempitan pada bagian tubuh terutama lengan dan pinggul. Banyak dari responden yang menyatakan setuju bila sebuah brand menyediakan ukuran dengan range yang besar dan ukuran yang fix pada tabel chart. Dari segi kualitas banyak yang menyatakan harga tidak perlu terlalu tinggi. Dari pengalaman belanja mereka tidak terpaku membeli dari satu brand saja. Kemudian adanya brand lokal plus-size membantu meningkatkan kepercayaan diri mereka.

\section{Metode Kualitatif}

Pada pengumpulan data secara kualitatif, narasumber yang dapat mewakili demografi responden terbesar dipilih untuk diwawancara. Wawancara dilakukan kepada 3 orang narasumber. Pertama mewakili umur $>40$ tahun, kedua dan ketiga mewakili umur 26 - 35th. Keduanya merupakan golongan responden terbanyak dalam kuesioner.

Wawancara dilakukan melalui telepon dan aplikasi zoom meeting dengan waktu yang terpisah masing-masing narasumber. Nama dari ketiga narasumber disamarkan untuk menjaga privasi mereka, dengan demikian penyebutan untuk narasumber hanya berupa inisial. Dari ketiga narasumber kemudian dibuat transkrip dalam bentuk tabel yang dapat dilihat pada tabel I.6. 
Tabel I. 6 Transkrip wawancara dengan narasumber. Data olahan Wardhani (2021)

\begin{tabular}{|c|c|c|c|}
\hline $\begin{array}{l}\text { Nara } \\
\text { sumber }\end{array}$ & $\begin{array}{l}\text { RR } \\
\text { - Bentuk } \\
\text { tubuh } \\
\text { straight/ } \\
\text { rectangle } \\
\text { - Usia > 40th } \\
\text { - Ibu Rumah } \\
\text { Tangga } \\
\text { - BB } 86 \text { - } \\
100 \mathrm{~kg}\end{array}$ & $\begin{array}{l}\text { GJ } \\
\text { - Bentuk tubuh } \\
\text { pear } \\
\text { - Usia 26-35th } \\
\text { - Dosen } \\
\text { - BB } 66-85 \mathrm{~kg}\end{array}$ & $\begin{array}{l}\text { WS } \\
\text { - Bentuk } \\
\text { tubuh } \\
\text { apel } \\
\text { - Usia 26 - } \\
\text { 35th } \\
\text { - Influencer } \\
\text { / } \\
\text { karyawan } \\
\text { swasta } \\
\text { - BB dulu > } \\
120 \mathrm{~kg} \\
\text { BB } \\
\text { sekarang } \\
86-100 \mathrm{~kg}\end{array}$ \\
\hline \multicolumn{4}{|l|}{ Desain } \\
\hline Trend & $\begin{array}{l}\text { Mengikuti } \\
\text { trend hanya } \\
\text { untuk jenis } \\
\text { pakaian formal } \\
\text { seperti ke } \\
\text { undangan } \\
\text { pernikahan, } \\
\text { tergantung } \\
\text { produsen } \\
\text { plus-size yang } \\
\text { kadang suka } \\
\text { telat mengikuti } \\
\text { trend }\end{array}$ & $\begin{array}{l}\text { Tidak mengikuti } \\
\text { trend }\end{array}$ & $\begin{array}{l}\text { Mengikuti } \\
\text { trend }\end{array}$ \\
\hline Basic & $\begin{array}{l}\text { Untuk pakaian } \\
\text { sehari-hari } \\
\text { memakai } \\
\text { pakaian basic }\end{array}$ & $\begin{array}{l}\text { Menyukai } \\
\text { pakaian basic } \\
\text { karena simpel }\end{array}$ & $\begin{array}{l}\text { Untuk } \\
\text { sehari- } \\
\text { hari suka } \\
\text { memakai } \\
\text { kaos dan } \\
\text { legging }\end{array}$ \\
\hline Pola unik & $\begin{array}{l}\text { Tergantung } \\
\text { yang } \\
\text { disediakan } \\
\text { produsen }\end{array}$ & Tidak & $\begin{array}{l}\text { Tergantung } \\
\text { yang } \\
\text { disediakan } \\
\text { produsen }\end{array}$ \\
\hline $\begin{array}{l}\text { Motif } \\
\text { besar }\end{array}$ & $\begin{array}{l}\text { Menyukai } \\
\text { motif yang } \\
\text { ramai dan } \\
\text { besar karena } \\
\text { percaya diri }\end{array}$ & $\begin{array}{l}\text { Motif lebih } \\
\text { suka yang } \\
\text { kecil dengan } \\
\text { pola seperti } \\
\text { bunga atau pola } \\
\text { geometris }\end{array}$ & $\begin{array}{l}\text { Menyukai } \\
\text { motif bunga } \\
\text { kecil atau } \\
\text { polos }\end{array}$ \\
\hline $\begin{array}{l}\text { Warna } \\
\text { mencolok }\end{array}$ & $\begin{array}{l}\text { Suka dengan } \\
\text { warna yang } \\
\text { mencolok }\end{array}$ & $\begin{array}{l}\text { Tidak menyukai } \\
\text { warna mencolok }\end{array}$ & $\begin{array}{l}\text { Tidak } \\
\text { menyukai } \\
\text { warna } \\
\text { mencolok }\end{array}$ \\
\hline
\end{tabular}

\begin{tabular}{|c|c|c|c|}
\hline \multicolumn{4}{|l|}{ Ukuran } \\
\hline $\begin{array}{l}\text { Pinggang } \\
\text { sempit }\end{array}$ & $\begin{array}{l}\text { Lebih ke } \\
\text { panjang baju } \\
\text { karena bentuk } \\
\text { badan tinggi }\end{array}$ & Tidak & $\begin{array}{l}\text { Lebih } \\
\text { kepada } \\
\text { lingkar dada } \\
\text { yang sempit }\end{array}$ \\
\hline $\begin{array}{l}\text { Lengan } \\
\text { baju } \\
\text { sempit }\end{array}$ & $\begin{array}{l}\text { Tidak terlalu } \\
\text { bermasalah }\end{array}$ & $\begin{array}{l}\text { Lengan baju jadi } \\
\text { sempit karena } \\
\text { dada yang } \\
\text { besar. Padahal } \\
\text { ukuran lengan } \\
\text { biasa saja }\end{array}$ & $\begin{array}{l}\text { Menyukai } \\
\text { pakaian } \\
\text { tanpa } \\
\text { lengan }\end{array}$ \\
\hline $\begin{array}{l}\text { Pinggang } \\
\text { celana } \\
\text { sempit }\end{array}$ & $\begin{array}{l}\text { Tidak terlalu } \\
\text { bermasalah, } \\
\text { masih ada } \\
\text { jegging }\end{array}$ & $\begin{array}{l}\text { Memakai } \\
\text { celana yang } \\
\text { stretch seperti } \\
\text { jegging. Tidak } \\
\text { ada lipatan } \\
\text { pinggang, } \\
\text { tapi paling } \\
\text { bermasalah } \\
\text { adalah bagian } \\
\text { paha dalam }\end{array}$ & $\begin{array}{l}\text { Lebih suka } \\
\text { memakai } \\
\text { rok atau } \\
\text { dress }\end{array}$ \\
\hline $\begin{array}{l}\text { Pinggul } \\
\text { celana } \\
\text { sempit }\end{array}$ & $\begin{array}{l}\text { Tidak terlalu } \\
\text { bermasalah }\end{array}$ & $\begin{array}{l}\text { Jarang beli } \\
\text { secara online, } \\
\text { belanja di Pasar } \\
\text { Baru Bandung } \\
\text { karena bisa } \\
\text { dicoba langsung } \\
\text { khususnya } \\
\text { celana }\end{array}$ & $\begin{array}{l}\text { Lebih suka } \\
\text { memakai } \\
\text { rok atau } \\
\text { dress }\end{array}$ \\
\hline $\begin{array}{l}\text { Range } \\
\text { ukuran } \\
\text { besar }\end{array}$ & $\begin{array}{l}\text { Lebih suka } \\
\text { brand regular } \\
\text { tapi } \\
\text { menyediakan } \\
\text { sizing yang } \\
\text { banyak hingga } \\
\text { 5L }\end{array}$ & $\begin{array}{l}\text { Lebih memilih } \\
\text { brand yang } \\
\text { menyediakan } \\
\text { range dari S } \\
\text { sampai yang } \\
\text { besar karena } \\
\text { bentuk badan } \\
\text { yang seperti } \\
\text { buah pir, jadi } \\
\text { ukuran atasan } \\
\text { bisa memakai } \\
\text { ukuran L }\end{array}$ & $\begin{array}{l}\text { Lebih } \\
\text { memilih } \\
\text { fokus } \\
\text { kepada } \\
\text { range } \\
\text { ukuran } \\
\text { yang } \\
\text { besar saja }\end{array}$ \\
\hline Ukuran fix & Suka bila fix & $\begin{array}{l}\text { Lebih suka } \\
\text { ukuran fix pada } \\
\text { tiap brand } \\
\text { sehingga tinggal } \\
\text { menghafal } \\
\text { brandnya apa, } \\
\text { jadi tidak usah } \\
\text { repot-repot ukur } \\
\text { tiap mau belanja }\end{array}$ & $\begin{array}{l}\text { Suka bila } \\
\text { fix sehingga } \\
\text { mudah } \\
\text { mengingat } \\
\text { brand }\end{array}$ \\
\hline
\end{tabular}


MODA volume 3 Nomor 2 Juli 2021

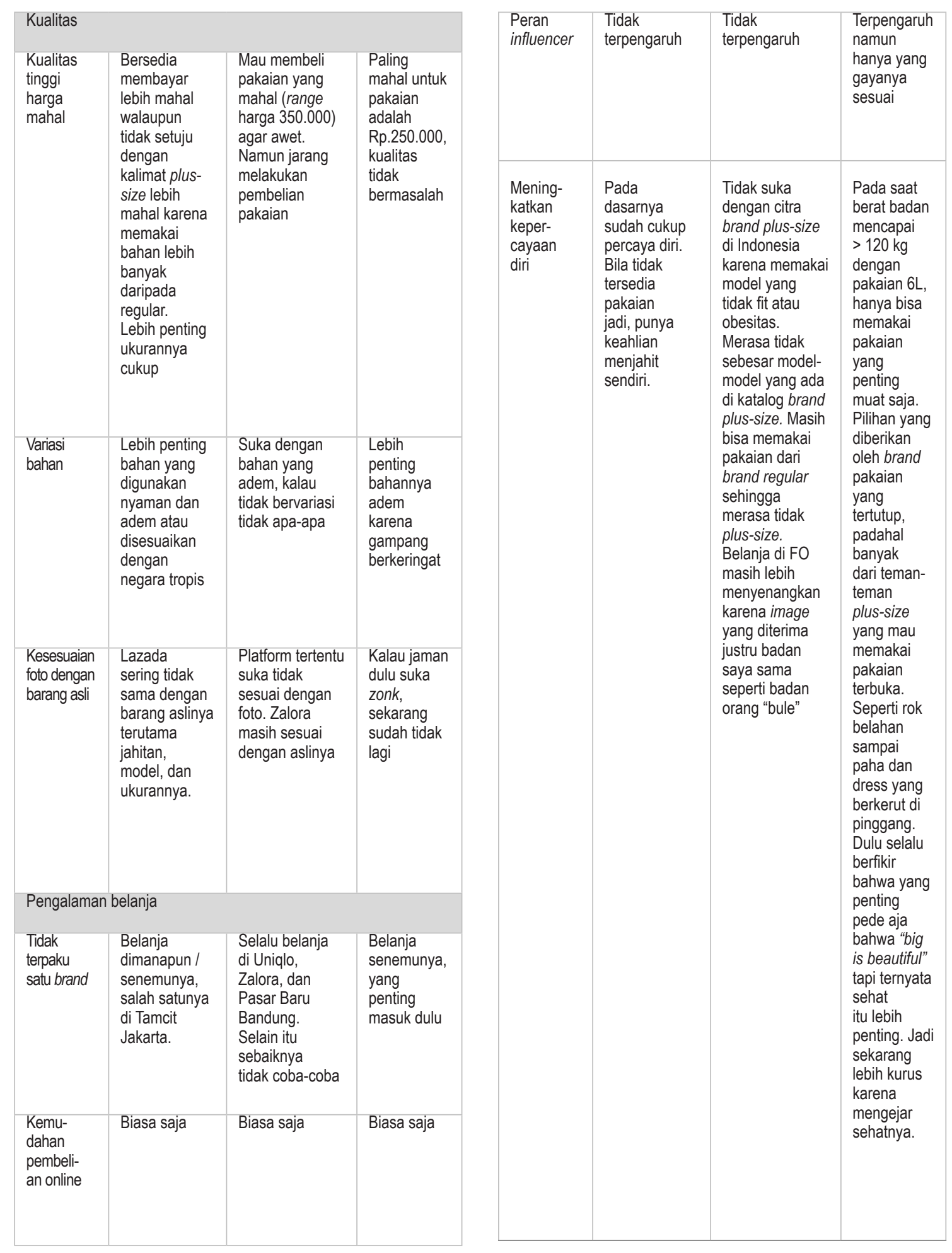


Berdasarkan wawancara tersebut diketahui bahwa minat belanja konsumen plus-size yaitu:

a. Faktor demografi sangat menentukan minat belanja konsumen plus-size. Seperti pendapatan, latar belakang etnis, dan pekerjaan.

b. Ukuran menjadi hal pertama dalam menentukan pembelian, diikuti desain dan kualitas.

c. Desain yang diinginkan adalah yang sesuai dengan bentuk tubuh. Desain tidak harus selalu menutupi seluruh badan.

d. Pemakaian bahan yang menyerap keringat dan harga yang relatif terjangkau.

e. Influencer tidak mempengaruhi minat belanja konsumen.

f. Masih tidak terbukanya konsumen plus-size akan berat badan mereka dalam angka.

g. Belanja online sudah lebih mudah dalam pengoperasiannya. Namun untuk kesalahan pembelian dalam hal ukuran masih terjadi. Untuk mengurangi kesalahan tersebutadayang membeli pakaian 1 nomor di atas yang biasa dipakai, atau tidak belanja online sama sekali.

h. Citra pada kata "plus-size" tidak ditanggapi secara baik. Faktor pertama karena citra tersebut merujuk kepada obesitas dan kesehatan. Kedua karena tidak semua bentuk tubuh merasa masuk ke dalam kategori plussize, seperti bentuk tubuh pir yang memiliki kecenderungan kecil pada bagian atas.

\section{Data Lapangan}

Tinjauan data lapangan dilakukan untuk menunjang kebutuhan data aktual yang sekiranya diperlukan dalam penelitian ini. Disini akan dijabarkan bagaimana variabel desain, ukuran, kualitas, dan pengalaman belanja konsumen pada website brand lokal plus-size di Indonesia. Tinjauan ini dilakukan setelah data kuesioner dan wawancara masuk. Penyajian data lapangan akan dijabarkan pada tabel I.7.

Tabel I. 7 Tinjauan data lapangan dari ke empat brand lokal plus-size. Data olahan Wardhani (2021)

\begin{tabular}{|c|c|c|}
\hline Variabel & Foto & Keterangan \\
\hline $\begin{array}{l}\text { Basic } \\
\text { dan trendy }\end{array}$ & & $\begin{array}{l}\text { Pada brand lokal } \\
\text { plus-size ke empat } \\
\text { brand lokal sudah } \\
\text { menyediakan dua } \\
\text { jenis pakaian basic } \\
\text { dan trendy, hanya } \\
\text { saja porsinya } \\
\text { berbeda-beda } \\
\text { pada tiap brand. } \\
\text { Brand My Size } \\
\text { (atas) lebih banyak } \\
\text { memiliki koleksi } \\
\text { pakaian basic } \\
\text { sedangkan brand } \\
\text { Pofeleve (bawah) } \\
\text { lebih banyak yang } \\
\text { mengikuti trend. }\end{array}$ \\
\hline
\end{tabular}



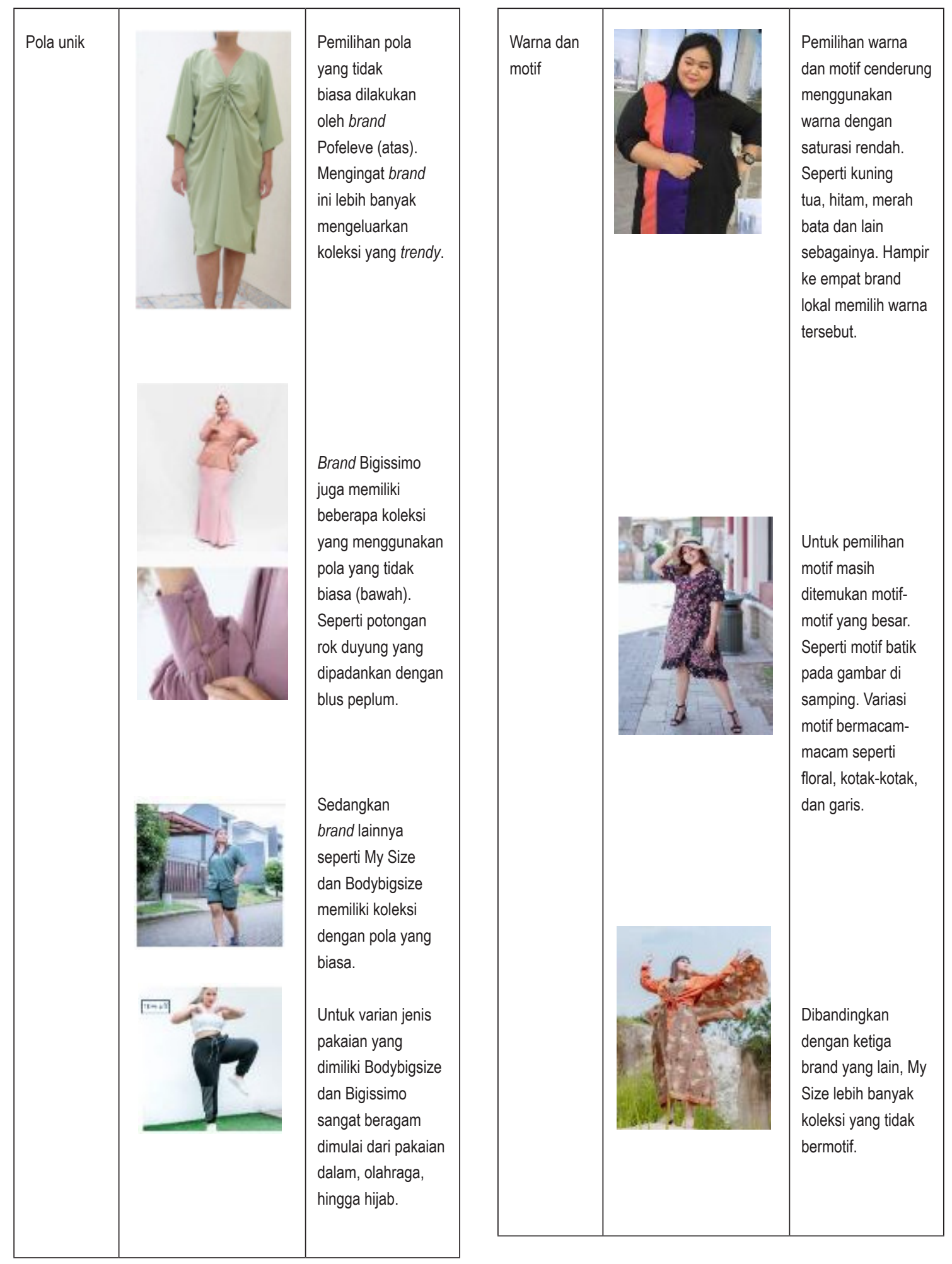


\begin{tabular}{|c|c|c|}
\hline $\begin{array}{l}\text { Informasi } \\
\text { ukuran }\end{array}$ & (1) & $\begin{array}{l}\text { Ke empat brand } \\
\text { lokal yang menjadi } \\
\text { penelitian, beberapa } \\
\text { diantaranya sudah } \\
\text { memakai chart } \\
\text { tabel ukuran. } \\
\text { Sedangkan sisanya } \\
\text { memakai deskripsi } \\
\text { pada halaman } \\
\text { pemilihan pakaian } \\
\text { dengan penulisan } \\
\text { keterangan ukuran } \\
\text { yang ditulis secara } \\
\text { konsisten. } \\
\text { Berbeda dengan } \\
\text { brand I wear alice } \\
\text { yang menuliskan } \\
\text { keterangan ukuran } \\
\text { yang selalu } \\
\text { berbeda-beda } \\
\text { setiap postingan } \\
\text { foto koleksi produk } \\
\text { mereka. }\end{array}$ \\
\hline $\begin{array}{l}\text { Variasi } \\
\text { bahan }\end{array}$ & $18 \mathrm{H}$ & $\begin{array}{l}\text { Rata-rata } \\
\text { penggunaan bahan } \\
\text { pada ke empat } \\
\text { brand adalah katun } \\
\text { untuk atasan dan } \\
\text { bahan yang stretch } \\
\text { untuk celana dan } \\
\text { legging. } \\
\text { Hanya beberapa } \\
\text { produk dari } \\
\text { Bodybigsize yang } \\
\text { menggunakan } \\
\text { bahan satin } \\
\text { maxmara untuk } \\
\text { koleksi pakaian tidur } \\
\text { mereka. }\end{array}$ \\
\hline
\end{tabular}

\begin{tabular}{|c|c|c|}
\hline $\begin{array}{l}\text { Kesesuaian } \\
\text { foto dengan } \\
\text { barang asli }\end{array}$ & (1) & $\begin{array}{l}\text { Kesesuaian } \\
\text { foto dengan } \\
\text { barang asli bisa } \\
\text { ditunjang dengan } \\
\text { menggunakan } \\
\text { fitur rating pada } \\
\text { toko online. } \\
\text { Brand Bigissimo } \\
\text { dan Bodybigsize } \\
\text { sudah memiliki } \\
\text { fitur rating pada } \\
\text { toko online mereka } \\
\text { sedangkan My } \\
\text { Size tidak punya. } \\
\text { Pofeleve memiliki } \\
\text { fitur yg sama } \\
\text { namun berhubung } \\
\text { toko e-commerce } \\
\text { mereka tidak aktif } \\
\text { jadi tidak ada review } \\
\text { dari konsumen. } \\
\text { Mereka lebih aktif } \\
\text { menggunakan } \\
\text { media sosial seperti } \\
\text { Instagram. }\end{array}$ \\
\hline Foto model & & $\begin{array}{l}\text { Brand Pofeleve } \\
\text { tidak konsisten } \\
\text { dalam memakai } \\
\text { model untuk foto } \\
\text { produk mereka. } \\
\text { Model yang } \\
\text { ditampilkan tidak } \\
\text { masuk ke dalam } \\
\text { kategori plus-size. } \\
\text { Hal ini dpaat } \\
\text { membingungkan } \\
\text { konsumen. }\end{array}$ \\
\hline
\end{tabular}


Brand lokal di Indonesia sudah berusaha dalam memenuhi kebutuhan konsumen plus-size dari segi desain, ukuran, kualitas dan pengalaman belanja.

\section{ANALISIS DAN PEMBAHASAN}

Dari hasil uji korelasi baik Rank Spearman dan Kendall Tau, terdapat hubungan yang positif dari antar variabel. Urutan hubungan antar variabel tersebut adalah ukuran, desain, dan kualitas. Ukuran dan desain masuk ke dalam kategori cukup, sedangkan kualitas masuk ke dalam kategori sangat lemah. Selanjutnya akan dibahas berdasarkan variabel penelitian yang sudah ditentukan yaitu desain, ukuran, kualitas, dan pengalaman belanja.

\section{Faktor Desain dan Ukuran}

Faktor desain dan ukuran adalah dua faktor utama yang menentukan minat belanja online konsumen plus-size. Hingga saat ini konsumen plus-size di Indonesia masih memiliki kesulitan untuk menemukan ukuran yang betul-betul pas pada saat melakukan belanja online. Setelah permasalahan mengenai ukuran terpenuhi, tahap kedua yang diperhatikan oleh konsumen plus-size di Indonesia adalah faktor desainnya. Berikut adalah penjabaran mengenai masingmasing faktor dan hubungan antar keduanya.

\section{Faktor Desain}

Seram \& Kumarasiri (2020) menggabungkan beberapa variabel sehingga menjadi 4 variabel penentu yang mempengaruhi desain. Cara seseorang berpakaian dapat mencerminkan kepribadian orang itu sendiri. Selain itu dapat pula menunjukkan kesukaan dari satu individu (Wan et al, 2007).

a. Trendy dan basic

Saat seseorang memilih satu pakaian tertentu, maka dia akan masuk ke dalam golongan kelompok yang memiliki pakaian yang serupa (Hassan \& Harun, 2016). Pada penelitian ini, diketahui pada usia responden terbagi menjadi dua kelompok besar. Pada golongan usia produktif yaitu 26 hingga 35 tahun dan usia dewasa akhir yaitu 40 tahun hingga 50 tahun. Apabila kita lihat kegiatan dari masing-masing kelompok, ada perbedaan yang sangat besar. Pada kelompok pertama, usia produktif 26 hingga 35 tahun. Bisa dikatakan mereka sedang aktif berkarier. Dalam berkegiatan seorang wanita yang bekerja di kantor memiliki kegiatan seperti meeting, bertemu klien, makan bersama kolega, dan lain-lain. Ada kebutuhan tersendiri dalam mengekspresikan diri sesuai dengan jabatan. Misalnya seorang manajer atau seorang pimpinan perusahaan, maka jenis pakaian yang akan ia pakai tentu harus mencerminkan status dan kedudukannya di perusahaan tersebut. Dalam demografi penelitian, dikatakan bahwa responden kedua terbesar adalah wanita pekerja 
swasta. Sayangnya disini tidak diperinci jenis pekerjaan responden. Sehingga tidak dapat terdeteksi apakah pekerja kantor swasta ini ada tuntutan dalam memakai pakaian tertentu. Seperti apabila bekerja di majalah atau pekerjaan yang menuntut untuk tampil stylish.

WS sebagai seorang pegawai kantoran sering memakai blus, kemeja dan rok span. Namun pada saat ia sebagai influencer, ia sering memakai dress tanpa lengan, blus, jaket panjang dan rok. GJ sebagai dosen, banyak menghabiskan waktunya di rumah dan di kampus. Dilihat dari kegiatan yang mereka lakukan, WS adalah target market yang masih bisa memakai pakaian yang mengikuti trend pada saat ia menjadi influencer. Sedangkan GJ memiliki kecenderungan memilih pakaian yang basic untuk kegiatannya. Bagi RR yang mewakili usia 40 hingga 50 tahun. la lebih menyukai pakaian basic dalam kegiatan sehari-hari. Tapi pada saat mengikuti acara formal, $\mathrm{RR}$ cenderung memilih pakaian yang trendy. Hal ini bisa jadi untuk mendukung status dari RR sebagai pensiunan yang dulunya sempat memiliki jabatan yang tinggi. Cara berpakaian ini dapat dikatakan berhubungan erat dengan status sosial dari masing-masing individu. Terlepas dari ukuran bentuk tubuh seseorang, baik wanita regular dan plus-size memiliki kepentingan dalam berpakaian yang disesuaikan dengan kondisi tempat mereka berpakaian.

Dalam memproduksi pakaian, sebuah brand harus dapat memenuhi kebutuhan target market. Alangkah lebih mudah bila penentuan target market sudah dilakukan serinci mungkin di awal pendirian brand. Target market yang jelas akan memudahkan brand dalam mengeluarkan koleksi pakaian yang cocok. Pemilihan jenis pakaian sebetulnya bisa dilakukan dengan menentukan jumlah prosentase pakaian yang trendy dan basic. Hal ini dapat menggapai lebih banyak konsumen ketimbang hanya fokus pada salah satu saja. Apalagi market plus-size yang sudah sangat khusus.

Dari ke empat brand lokal yang diteliti, brand Poveleve adalah satu brand yang memiliki koleksi pakaian yang mengikuti trend lebih banyak ketimbang baju basicnya. Seperti koleksi pakaian tie dye atau ikat yang bekerja sama dengan influencer. Melihat dari hal tersebut, bisa jadi target market yang diincar oleh brand Poveleve adalah wanita plus-size yang senang akan trend dan aktif bermain sosial media. Sedangkan untuk brand lainnya seperti My Size, Bodybigsize dan Bigissimo memiliki porsi yang hampir banyak pada koleksi pakaian basic. 


\section{b. Pola unik}

Menurut Hassan \& Harun (2016) faktor keunikan merupakan bentuk dari ekspresi diri. Kebutuhan akan menjadi berbeda dengan kebanyakan merupakan suatu hal yang diidamkan orang dengan pengetahuan fesyen yang tinggi. Kebutuhan akan berekspresi dan keinginan menjadi berbeda belum tampak pada konsumen plus-size di Indonesia. Tentunya konsumen plussize sudah merasa berbeda dibandingkan dengan konsumen reguler. Perbedaan mencolok pada ukuran badan menjadikan mereka justru ingin terlihat sama dengan konsumen reguler.

Pola yang unik identik dengan cutting pakaian yang tidak biasa. Terkadang, cutting pakaian yang aneh belum tentu cocok dipakai oleh semua tipe ukuran badan. Seorang desainer harus memperhatikan pola pakaian yang enak dipakai dan bagus dilihat. Sebuah ilusi optik dapat diciptakan melalui desain pola dari pakaian. Ilusi tinggi, kurus, pendek, dan gemuk bisa diciptakan baik dari pemilihan motif dan potongan pola pakaian. Disinilah makna keunikan yang lebih dibutuhkan oleh konsumen plus-size, dibandingkan dengan pola unik seperti pakaian yang bisa dicopot pasang misalnya.

Berbicara mengenai pola pada pakaian. Konsumen plus-size memiliki kebutuhan pola pakaian yang berbeda dengan konsumen reguler. Biasanya grading pada pakaian adalah penambahan sebesar 1,5 hingga $2 \mathrm{~cm}$ yang dilakukan bersamaan pada bagian pinggang, pinggul, bahu, dan panjang pakaian. Bagi konsumen plussize, penambahan ini tidak bisa dilakukan bersamaan dan harus mempertimbangkan tipe bentuk tubuh. Misalnya bentuk tubuh pir yang memiliki pinggul yang besar, akan membutuhkan penambahan pada pinggul lebih lebar daripada bagian pinggang. Grading yang berbeda ini sebaiknya dibuat berdasarkan tipe bentuk tubuh agar memudahkan pembuat pola.
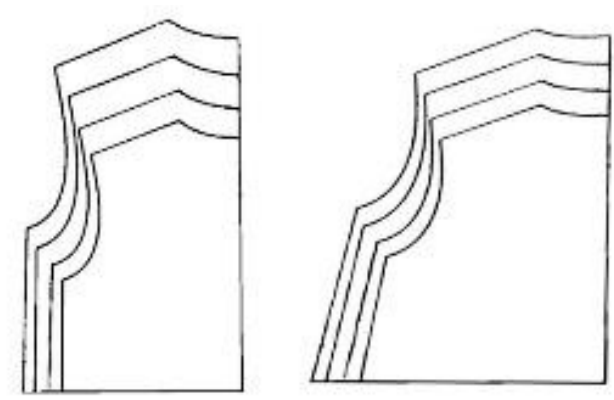

Gambar I 2 Grading pada pakaian wanita plus-size. Ilustrasi oleh Wardhani (2021)

Pada brand lokal, biasanya untuk proses produksi terdapat 2 cara. Mereka memiliki operator pola sendiri atau menggunakan jasa outsource seperti makloon atau konveksi. Pada jasa makloon atau konveksi biasanya mereka sudah memiliki pola sendiri sehingga pemilik brand tinggal mengikuti apa kata mereka. Inilah yang harus diperhatikan mengingat konsumen plus-size memiliki perbedaan dengan 
konsumen reguler. Brand My Size memiliki pola pakaian yang cenderung polos dan standar. Dengan pemilihan jenis pakaian seperti kemeja, kaos, blus, dan dress. Cutting seperti princess jarang ditemui pada ke empat brand yang diteliti.

Pada wawancara disebutkan bahwa tidak perlu baju yang aneh-aneh. Pola yang unik pada akhirnya berhubungan dengan style pakaian yang unik. Pertimbangan tidak perlunya baju yang aneh menunjukkan bahwa konsumen plus-size lebih membutuhkan pakaian yang praktis. Mereka sudah merasa ribet dengan memilih pakaian yang muat sehingga tidak perlu dibuat lebih ribet lagi.

\section{c. Motif dan warna}

Pada kuesioner disebutkan bahwa mereka menganggap faktor motif dan warna netral, namun hanya satu suara dengan sangat tidak setuju. Menunjukkan bahwa kebanyakan dari konsumen plus-size terutama di Jawa Barat lebih memilih menggunakan pakaian dengan warna yang tidak mencolok dan motif yang polos. Dalam wawancara mendalam, RR mengatakan tidak masalah dengan warna dan motif yang besar atau terang. Setelah digali lebih dalam, terkuak bahwa walaupun RR berdomisili di Bekasi, namun suku asli RR adalah berasal dari Madura. Bisa ditelaah lebih lanjut bahwa biasanya kecenderungan pakaian yang dipakai oleh orang dari suku Madura biasanya cerah dan tabrak warna.
Seperti yang dikatakan oleh Mudjjjono (2016) dalam penelitiannya mengenai makna batik Madura dikatakan bahwa pemakaian warnanya selalu warna cerah seperti biru, oranye, kuning, merah. Lain dengan GJ yang lebih menyukai warna cenderung kalem seperti hitam, coklat, dan putih. GJ yang sejak lahir berdomisili di Bandung kemungkinan selera berpakaiannya terpengaruh oleh lingkungan.

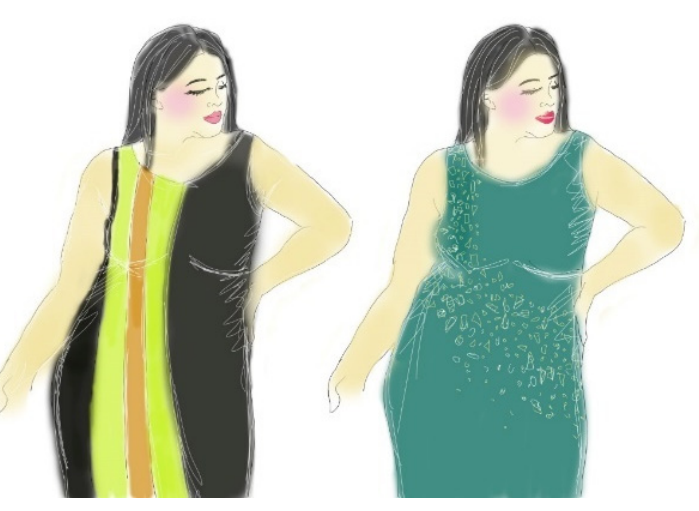

Gambar I 3 Penempatan motif dan warna untuk memberikan ilusi optik pada wanita plus-size. Ilustrasi oleh Wardhani (2021)

Motif dan warna adalah elemen yang dapat memberikan efek instan untuk menarik perhatian orang lain saat melihat seseorang berpakaian. Motif besar dan warna cerah akan menarik mata untuk langsung tertuju ke motif atau warna tersebut. Maka dari itu, pengetahuan seorang desainer akan bentuk tubuh akan membantu dirinya dalam membuat desain pakaian yang sesuai dengan kebutuhan dari masing-masing bentuk tubuh. Misalnya bentuk tubuh rectangle yang memiliki 
lebar bahu, pinggang, dan pinggul hampir sama membutuhkan highlight pada bagian pinggang. Jadi apabila seseorang dengan bentuk tubuh rectangle dapat memakai dress dengan motif garis-garis vertikal dan warna sebagai highlight seperti yang diilustrasikan pada gambar

Pada ilustrasi 1.3, ada upaya untuk mengarahkan mata kepada garis oranye dan hijau sehingga akan memberikan sebuah ilusi bahwa bentuk tubuhnya hanya berada di area tersebut. Untuk ilustrasi ke dua, motif yang diletakkan di pinggang supaya mata mengarah ke lingkar paling kecil pada tubuh.

Selama bertahun-tahun pada setiap literatur populer seperti majalah menyebutkan bahwa wanita plus-size sebaiknya memakai pakaian yang gelap untuk memberikan kesan siluet yang kecil pada tubuh mereka. Namun tahun 2021 ini, dunia mulai bergerak ke arah penerimaan body diversity, dimana kita bisa menemukan bentuk tubuh yang tidak seperti model terpampang di sampul majalah atau menjadi model iklan.

Maka bila dibandingkan dengan tahun 2000an, kita bisa melihat bagaimana wanita plus-size di dunia dapat lebih berekspresi. Konsumen di Indonesia akan menuju kesana dengan mulai banyaknya influencer yang menjadi aktivis body positivity.

\section{Faktor Ukuran}

Faktor ukuran merupakan hal yang paling krusial pada konsumen plus-size. Terlihat baik pada wawancara dan kuesioner bahwa setidaknya konsumen plus-size pernah mengalami kesempitan pada satu bagian tubuh. Paling banyak adalah pada bagian lengan (44,3\%) dan pinggul $(50,6 \%)$. Hal ini dapat disebabkan oleh banyak faktor, seperti misalnya kasus yang sering dijumpai GJ. la mengalami kesempitan pada lengan bukan karena lengannya yang besar, tapi lebih karena dadanya yang besar. Sehingga lubang lengan pada baju yang dipakai GJ tertarik ke arah dada dan membuat bagian lengan menjadi tidak enak dipakai. Pada RR yang memiliki postur yang tinggi, ia sering menjumpai pakaian yang kependekan pada bagian blus, celana, dan lengan. Kemudian adapula dijumpai kasus-kasus seperti menipisnya bahan kain pada tempat-tempat tertentu. Misalnya yang dialami oleh GJ dan WS, mereka sering lecet pada bagian paha dalam atau jeans yang mereka pakai sering lebih dulu robek di bagian tersebut. Kasus seperti ini banyak dijumpai oleh konsumen plus-size karena adanya gesekan antara kulit dan pakaian yang lebih intens. Biasa ditemukan pada bagian paha dalam celana, bagian punuk punggung, dan bagian dada.

Hal ini dapat menjadi catatan yang penting untuk desainer pada sebuah brand dimana mendesain pakaian untuk konsumen plus-size bisa dilakukan dengan mengkategorikan bentuk tubuhnya terlebih dulu, untuk memudahkan 
proses mendesain. Kemudian ditambah dengan catatan-catatan khusus tadi. Sehingga konsumen yang memiliki bentuk tubuh pir misalnya, mendapatkan desain celana yang lebih tebal pada bagian paha dalam. Desain seperti ini akan membuat pakaian lebih awet dan dipastikan tepat sasaran. Ketiga narasumber mengatakan bahwa faktor ukuran menjadi hal utama pada saat pembelian pakaian. Kalau bajunya muat, baru mereka akan memikirkan faktor-faktor lainnya. WS mengatakan dalam wawancara setelah ia bisa menurunkan berat badan dan menggunakan ukuran $3 \mathrm{~L}$, ia merasa pilihan dalam berpakaian menjadi lebih banyak. Kita bisa menyimpulkan bahwa industri pakaian di Indonesia belum sepenuhnya memenuhi kebutuhan dari berbagai macam ukuran konsumen. Mengapa akhirnya GJ lebih memilih untuk membeli pakaian di Factory Outlet FO (FO), karena baju di FO kebanyakan adalah sisa pakaian ekspor. Dengan demikian, ukuran yang ada di FO adalah ukuran yang diperuntukkan bagi konsumen di luar Indonesia.

Ukuran di Indonesia tidak terpaku kepada standarisasi yang sudah ditetapkan oleh SNI. Padahal dalam SNI terdapat ukuran pakaian untuk blus wanita. Sama seperti di luar negri, pada praktiknya tiap brand memiliki ukuran sendiri yang dirasa cocok untuk masing-masing konsumen mereka. Dalam hal pembuatan pola pakaian, akan lebih baik bila sebuah manufaktur atau brand memiliki pola sendiri yang dibuat berdasarkan bentuk tubuh. Seperti yang sudah sempat disinggung pada pembahasan pola yang unik, grading pada pakaian plus-size tidak bisa disamakan dengan pola badan reguler.

Pada pembelian secara online, ukuran masih menjadi hal yang cukup rumit baik untuk konsumen reguler, apalagi untuk konsumen plus-size. Tapi hal ini tidak mengurangi antusias konsumen untuk melakukan pembelian secara online. Berjamurnya brand baru yang menjual produknya secara online membuktikan bahwa pasarnya ada. Dilihat dari pembagian secara demografis, usia dewasa akhir sudah paham akan detil ukuran mereka dibandingkan dengan usia dewasa awal. Apalagi usia delapan belasan dimana mereka baru merasa dewasa dan bisa melakukan belanja mandiri tanpa dampingan orang tuanya. Pada Youtube dan Tiktok, dapat ditemukan banyak tutorial cara memesan pakaian secara online agar tidak salah ukuran. Banyak dari para komentator yang disinyalir berusia 18 hingga 20 tahun yang menyatakan bahwa mereka merasa kebingungan dan mengalami salah beli ukuran. Sedangkan usia 30 hingga 50 sudah lebih mengenal diri mereka dan hapal akan lingkar dada, pinggang, dan pinggul mereka diluar kepala.

Styling pada pakaian tentu mempengaruhi ukuran dari pakaian itu sendiri. Sekarang ini banyak styling pakaian oversized yang mengambil gaya dari street style. Trend pakaian dengan kaos kebesaran, celana baggy, dan sneakers menjadikan konsumen kebingungan atas pembagian ukuran mereka. Trend oversized 
ini membuat frustasi konsumen plus-size karena ukuran yang seharusnya diperuntukkan mereka, dibeli oleh konsumen regular yang ingin tampil mengikuti trend. Sehingga semakin terbataslah pilihan bagi konsumen plus-size. Untuk mengingkapi hal ini, sebuah brand dapat menyatakan bahwa produk mereka khusus untuk konsumen plus-size, atau mereka dapat memberikan pilihan kepada konsumen untuk pakaian yang fit pada badan atau oversized.

Dalam kuesioner banyak yang mengatakan setuju apabila sebuah brand memiliki range ukuran yang besar $(74,7 \%)$, hal ini bisa dipenuhi oleh brand dengan modal yang kuat. Brand lokal di Indonesia dengan modal yang kuat seperti My Size dan Bodybigsize mampu menyediakan koleksi dengan ukuran yang banyak (dari XXL hingga $8 \mathrm{XL}$ ). Penyediaan ukuran yang besar ini dapat menjadi sebuah strategi yang praktis untuk menjangkau pasar yang luas. Selain itu menyangkut persoalan style pakaian oversized sebelumnya, dengan memiliki ukuran yang beragam dapat tetap memenuhi keinginan pasar walaupun ukuran tubuhnya berbeda-beda. Berbeda dengan brand MySize dan Bodybigsize, Pofeleve dan Bigissimo membagi range ukuran hanya tiga ukuran. Hal ini bisa jadi untuk meminimalisir pengeluaran ongkos produksi dan menghindari terjadinya stok mati (dead stock). Strategi yang cocok untuk brand lokal yang memiliki modal kecil adalah menyediakan sistem pre-order (PO). Kelebihan sistem PO adalah tidak perlu menyediakan gudang yang besar untuk penyimpanan barang dan dapat menekan ongkos produksi. Di Indonesia sistem PO bukan hal baru. Brand reguler juga banyak yang menggunakan sistem ini di e-commerce. Dulu adanya toko online adalah untuk memenuhi kebutuhan konsumen secara cepat, namun sekarang terdapat indikasi konsumen mau menunggu barang yang mereka beli. Terutama untuk konsumen dengan pendapatan yang tinggi dan generasi $Z$.

Untuk pertanyaan mengenai ukuran fix atau tidak, banyak yang menyatakan menyukai dengan ukuran yang fix (57\%). Artinya konsumen menginginkan produk yang mereka beli jelas. Adanya ukuran yang sudah ditentukan di awal, memudahkan mereka dalam menentukan produk dan mudah saat nanti melakukan pembelian ulang. Keterangan ukuran pada berbagai platform harus sama dan ditulis dengan format yang sama pula. Seperti halnya membeli barang elektronik, apabila pakaian juga menuliskan atribut yang jelas dan sama pada tiap artikelnya maka kepercayaan konsumen akan meningkat dan menurunkan resiko terjadinya kesalahan pembelian.

Ke empat brand pada penelitian ini sudah menggunakan ukuran yang fix. Meskipun beberapa diantara brand tersebut masih menuliskan keterangan ukuran secara deskriptif, namun penulisan tersebut ditulis sama pada setiap platform penjualan. Konsistensi ini dapat menjadi langkah awal dalam meningkatkan kepercayaan konsumen. 


\section{Faktor Kualitas}

Bagi pemilik brand, harus memperhatikan segala aspek dalam penjualan. Baik dari segi produknya maupun platform penjualannya. Sehingga kualitas dapat dilihat dari kedua sisi, baik produk maupun kualitas tampilan website atau media sosial.

1. Kualitas produk

Pada pertanyaan mengenai pemakaian bahan, konsumen plus-size menyukai pakaian dengan bahan yang adem. Dari kedua golongan usia, responden menyatakan bahwa pakaian yang adem dibutuhkan di negara dengan cuaca tropis seperti Indonesia. Pada saat wawancara RR menyatakan bahwa pakaian impor yang ada di mall biasanya berasal dari negara empat musim. Sehingga kadang pakaian yang tersedia menggunakan bahan tebal untuk musim dingin. Untuk pasar di Bandung mungkin masih bisa terpakai namun untuk konsumen di daerah Bekasi tidak cocok.

Bahan yang menyerap keringat akan sangat diperlukan bagi konsumen di Indonesia. Banyak dari pekerja swasta yang menggunakan transportasi umum ke kantor mereka. Variasi bahan yang cocok untuk negara tropis seperti katun adalah pilihan yang cocok. Selain bahan alami seperti katun, Indonesia memiliki bahan yang banyak untuk memproduksi rayon. Rayon juga memiliki karakteristik seperti katun yaitu sejuk dan mudah menyerap keringat. Selain bahan yang mudah menyerap keringat dan adem, konsumen plus-size akan lebih baik bila memakai bahan yang tidak gampang kusut. Dengan banyaknya permukaan yang bergesekan, akan lebih mudah bila pakaian yang mereka kenakan tidak mudah kusut dan mudah disetrika. Hal ini akan membuat si pemakai terlihat rapi.

Dari ke empat brand lokal yang dipilih, ke empatnya rata-rata memakai bahan seperti katun, kaos, dan sifon. Namun di Indonesia sering ditemukan perbedaan nama bahan dengan nama umum. Misalnya ada kain yang dinamakan oleh pengecer kain seperti maxmara, sakura sweding, wolfice adalah nama-nama pasar yang tidak semua orang tau seperti apa karakteristiknya. Maka daripada nama bahan ditulis dengan nama pasar, lebih baik dicari tau material yang terkandung dalam kain tersebut. Contoh brand Zara yang menuliskan material ketimbang nama dari bahan yang mereka pakai.

2. Kualitas tampilan pada platform media sosial Pada penjualan barang secara online, konsumen dihadapkan kepada layar gawai mereka bukan kepada orang yang dapat diajak berkomunikasi secara langsung. Sehingga kepercayaan konsumen menjadi sangat penting. Hasil penelitian menunjukkan bahwa konsumen plus-size di Indonesia tidak mau mengeluarkan uang lebih walaupun mendapat kualitas yang tinggi $(30,4 \%)$. Disini kepercayaan pada platform online bisa jadi 
belum terbentuk. Dari pernyataan GJ, bisa disimpulkan bahwa ia lebih memilih belanja di FO dan Pasar Baru. Hal ini GJ lakukan karena ia merasa pasti mendapat ukuran yang pas dibanding belanja online dan kecewa. WS yang paling sering berbelanja online dibandingkan dengan narasumber lainnya, menyatakan bahwa untuk belanja pakaian uang yang mau ia keluarkan maksimal adalah Rp.250.000. Pada platform online terutama e-commerce, bila kita klik berdasarkan jenis pakaian akan langsung keluar bermacammacam gambar produk dari harga lima puluh ribu hingga jutaan. Konsumen sangat leluasa untuk membandingkan produk pada saat belanja online. Namun karena takut akan mengalami diskonfirmasi negatif atas pembelanjaan, biasanya konsumen cenderung memilih produk yang murah tapi dengan tampilan yang menarik. WS sempat mengatakan ia beberapa kali belanja online dan salah ukuran, tapi ia tidak melakukan pengembalian atau retur.

Merujuk pada pertanyaan kesesuaian foto dengan barang asli, responden menjawab netral pada angka $48,1 \%$. Artinya foto dan barang yang diterima konsumen tidak ada masalah. Setelah ditelusuri ada kecenderungan konsumen merasa wajar untuk menerima kualitas yang biasa saja untuk produk dengan harga yang murah. Sehingga mereka tidak meretur dan tetap memberikan rating bintang 4 atau 5 . Sering ditemukan komentar "sesuai dengan harga" pada kolom rating di e-commerce. Sedangkan dari hasil pengamatan, produk dengan harga dua ratus lima puluh ribu rupiah hingga jutaan jarang sekali ada pembelian. Hal ini berbanding terbalik dengan penjualan gadget atau barang elektronik. Meskipun dari ke empat brand yang diteliti memiliki penjelasan yang dibutuhkan konsumen, namun ada baiknya terdapat suatu standarisasi atau sistem yang mewajibkan seluruh penjual online memiliki keterangan yang sama satu dan lainnya. Seperti halnya pada barang elektronik, terdapat penjelasan spek yang sama pada tiap barang sehingga konsumen mudah untuk membandingkan dan menghapal produk yang akan ia beli. Fitur ini bisa diberlakukan oleh marketplace untuk para tenantnya.

Di Indonesia masih terdapat daerah-daerah yang baru saja 'melek' belanja online, seperti wilayah Sulawesi Barat. Namun demikian pada pertanyaan kuesioner mengenai kesesuaian produk yang diterima konsumen dengan tampilan foto pada website dinyatakan netral $(48,1 \%)$. Hal ini menunjukkan bahwa kota besar terutama di daerah Jawa masyarakatnya sudah terbiasa dalam melakukan belanja online, sedangkan untuk konsumen di luar Jawa masih dipertanyakan. Ariyanti (2019) dalam tulisannya menyatakan bahwa profesi yang paling banyak belum 'melek' belanja online adalah ibu rumah tangga. Hal ini berbeda 
dengan hasil penelitian bahwa demografis terbesar adalah ibu rumah tangga dan pegawai swasta.

Dalam wawancara RR menyatakan bahwa ia bisa melakukan pembelian online lewat e-commerce dan merasa bahwa barang yang diterima baik-baik saja. Meskipun demikian, ada kekhawatiran sebelum melakukan belanja secara online. RR telah teredukasi secara baik dalam melakukan belanja online. Seperti misalnya ia akan cek dulu kolom komentar, rating, toko yang sudah verified, dan lain sebagainya. Bagi WS yang lebih sering melakukan belanja online, toko online sekarang sudah lebih bagus daripada jaman awal-awal adanya penjualan secara online. Menurut pengalaman WS, dulu ia sering mendapati barang yang jauh berbeda dengan aslinya. Artinya semakin kesini produsen juga semakin baik dalam menjual produk disertai dengan keterangan produk akan membuat konsumen semakin percaya. Semakin tinggi tingkat kepercayaan konsumen, akan semakin banyak pula tingkat penjualan barang.

\section{Faktor Pengalaman Belanja Online}

Belanja online di tahun 2021 ini bukan hal yang baru. Hampir seluruh orang dari berbagai generasi dan kelas sosial dapat melakukan belanja online. Namun loyalitas dari konsumen plus-size di Indonesia masih belum terbentuk. Pada kuesioner sebanyak $53,2 \%$ menjawab sangat setuju untuk pertanyaan tidak terpaku pada satu brand. Disini yang bisa ditelaah adalah apakah brand lokal di Indonesia memang belum memenuhi kebutuhan yang dicari oleh konsumen atau memang tidak adanya perbedaan antara brand satu dan yang lain sehingga konsumen tidak merasa adanya engagement terhadap satu atau dua brand.

Loyalitas konsumen dapat ditandai dengan bagaimana mereka mengingat satu brand. Dari hasil wawancara dengan narasumber, hanya brand My Size yang disebut oleh ketiganya. My Size merupakan brand pionir yang menjual pakaian plus-size di Indonesia. Sebelum melakukan penjualan secara online brand ini sudah memiliki banyak gerai di seluruh Indonesia. Inilah sebabnya brand My Size diingat oleh konsumen. Hal ini menandakan bahwa brand plus-size lainnya belum memiliki branding yang kuat. Kerjasama dengan influencer adalah salah satu cara agar konsumen dapat mengingat sebuah brand. Pemilihan influencer yang diajak bekerja sama harus sesuai dengan target market masing-masing brand. Dari data penelitian diketahui bahwa peran influencer dianggap netral (43\%), dan pada wawancara terlihat bahwa konsumen akan melihat influencer yang dekat dengan dirinya. Bila konsumen merasa adanya kedekatan emosional (baik dari style atau gaya hidup) dengan influencer tersebut, baru ia akan mengikuti apa yang dikenakan oleh mereka. Seperti yang dialami GJ dan WS. GJ merasa influencer plus-size di Indonesia yang ia tau memiliki style yang terlalu heboh sehingga 
mereka tidak mempengaruhi pembelian untuk GJ pribadi. Sedangkan WS mengatakan bahwa apabila style dari influencer yang ia lihat sesuai maka ia akan membeli produk yang sama. Sesuai dengan teori customer behavior bahwa demografis dapat menjadi penentu konsumen dalam berperilaku. Penting sekali untuk sebuah brand memiliki target market yang jelas dari segi usia, geografis, dan kelas sosial.

Dari keempat brand yang diteliti. Pofeleve sering bekerjasama dengan influencer dibanding brand lainnya. Tapi efek dari endorse ini tidak terlihat terhadap penjualan mereka. Mereka cenderung lebih lambat dalam mengeluarkan koleksi baru dan pada tahun 2020 mereka harus mengurangi pekerja mereka karena pandemi.

Kehadiran brand lokal plus-size di Indonesia dianggap menjawab kebutuhan konsumen plussize. Dari pertanyaan kuesioner diketahui bahwa hadirnya brand lokal meningkatkan rasa percaya diri $(54,4 \%)$. Dalam wawancara pun WS dan RR mengatakan dulu mereka susah sekali mencari pakaian yang muat. RR kemudian memilih untuk menjahit sendiri.

Usia dapat mempengaruhi pengalaman belanja karena cepatnya perubahan teknologi menentukan bagaimana sistem belanja online akan terus berubah. Biasanya generasi yang lebih tua akan sulit untuk mengikuti perubahan-perubahan tersebut karena dipaksa menyesuaikan diri dengan cepat. Sedangkan untuk konsumen dengan usia dewasa dan lebih muda biasanya lebih cepat dalam penyesuaian bila terdapat perubahan pada sistem toko online. Maka dari itu disini tiap brand harus jelas siapa konsumen yang dituju karena hal tersebut akan berpengaruh kepada seluruh sitem penjualan dan produk yang akan dijual.

\section{Rangkuman Analisis}

Berdasarkan analisis di atas didapatkan kesimpulan-kesimpulan sebagai berikut:

a. Hubungan antara variabel desain, ukuran, kualitas terhadap pengalaman belanja konsumen plus-size adalah positif. Urutan hubungan tersebut adalah ukuran, desain, kemudian kualitas. Variabel kualitas masuk ke dalam kategori sangat lemah. Hubungan dari faktor ukuran terhadap desain dan kualitas terletak pada adanya kebutuhan khusus pada konsumen plus-size untuk memperhatikan lebih lanjut pada ukuran bentuk tubuh. Ukuran bentuk tubuh yang banyak dimiliki oleh konsumen plus-size di Indonesia adalah apel, pir, dan hourglass. Dari sisi produsen atau brand, bentuk tubuh akan menentukan desain yang tepat bagi pemakainya. Selain itu desainer dapat membuat sebuah ilusi optik bagi konsumen plus-size karena berbeda dengan kosumen reguler, ilusi optik akan sangat membantu mereka dalam berpakaian agar terlihat lebih langsing atau lebih tinggi. Pola pakaian plussize juga berbeda dengan konsumen reguler. Dengan menggunakan bentuk tubuh, brand 
akan mampu membuat ilusi optik lewat pembuatan pola.

b. Grading pada pola akan membantu produsen dalam membuat chart ukuran yang pasti dan fix seperti yang diminati oleh konsumen plussize. Dengan ukuran yang fix konsumen tidak akan bingung karena mereka dapat mengingat ukuran pada satu brand tertentu. Ketersediaan ukuran yang besar dapat dilakukan oleh brand dengan modal yang kuat sedangkan untuk brand yang masih kecil atau baru memulai bisa menggunakan sistem PO. Dengan adanya sistem ini akan mempermudah baik brand maupun konsumen yang akan membeli.

c. Untuk membangun kepercayaan konsumen, informasi yang disampaikan oleh brand pada toko online harus tersampaikan dengan jelas. Dengan menentukan target market brand akan lebih mudah memahami karakter dari konsumen yang dituju. Secara umum, brand lokal di Indonesia sudah memiliki penyampaian informasi yang jelas pada toko online mereka. Hal ini bisa dioptimalkan dengan menambahkan edukasi untuk konsumen. Seperti edukasi mengenai bahan yang dipakai, seperti apa bahan tersebut ketika dipakai, dan bagaimana efek terhadap iklim di Indonesia. Kemudian mengenai bentuk tubuh dan cara untuk styling pakaian sesuai dengan bentuk tubuh masing-masing. Edukasi ini bisa disampaikan melalui media sosial dalam bentuk foto, video, atau infografis.

d. Dari tampilan website adanya penambahan fitur seperti pengkategorian bentuk tubuh akan sangat memudahkan konsumen dalam memilih pakaian. Dengan UI yang menarik dan grafis yang enak dilihat, konsumen tidak akan merasa waktunya terbuang untuk mengisi form pada awal membuat profil karena akan terjamin mendapatkan kualitas yang sebading.

e. Adanya standarisasi pada informasi produk yang ditampilkan akan memudahkan konsumen dalam belanja online. Seperti halnya pada saat pembelian gadget dimana spesifikasi barang dituliskan secara rinci dan sama setiap toko maka akan ada kepercayaan pada toko sehingga tercipta pembelian.

f. Adanya edukasi diharapkan akan terbentuk engagement dari brand dan konsumen plussize sehingga tercipta brand awareness yang sekarang masih belum ada. Brand plus-size dapat membuat konten yang disesuaikan dengan target market masingmasing. Adanya upaya-upaya ini akan membantu meningkatkan penjualan yang strategis dimana pasar konsumen plus-size ini masih akan mengalami pertumbuhan. Apalagi hadirnya brand plus-size terbukti meningkatkan kepercayaan diri dari konsumen plus-size. 
g. Pada penelitian ini responden yang banyak terlibat adalah responden dengan umur 26 hingga 50 . Namun bila melihat pertumbuhan angka obesitas dimulai dari usia 18 tahun dengan gaya hidup konsumsi makanan instan dan junkfood maka dapat diprediksi adanya peningkatan jumlah konsumen plussize yang lebih muda dari usia 18 dikemudian hari. Sehingga potensi dari adanya brand lokal plus-size ini sangat besar.

\section{KESIMPULAN}

Permasalahan ketidaksesuaian produk yang diiklankandengan produkyang diterimakonsumen mengakibatkan rendahnya tingkat kepuasan dari pelanggan. Hal tersebut dapat menjadikan minat belanja online menjadi menurun terutama pada konsumen plus-size yang tergolong masih baru. Faktor yang dapat meningkatkan minat belanja konsumen adalah faktor desain, ukuran, kualitas, dan pengalaman berbelanja online. Brand plussize lokal di Indonesia seperti My Size, Bigissimo, Big Body Size, dan Pofeleve dapat menjadi acuan karena termasuk brand yang diingat oleh konsumen. Dari hasil penelitian diketahui bahwa hubungan antar variabel bisa dikatakan positif, meskipun demikian hubungan tersebut lemah pada faktor kualitas. Urutan dari variabel atau faktor penentu minat belanja online konsumen plus-size adalah ukuran, desain, pengalaman belanja baru kemudian kualitas. Sehingga brand lokal dapat lebih fokus untuk mengingkatkan faktor kualitas baik dari segi kualitas produk dan kualitas platform tempat berjualan online.
Dari ke empat brand lokal yang diteliti dapat diketahui bahwa ke empatnya sudah memiliki informasi yang cukup dalam merepresentasikan kebutuhan akan faktor desain, ukuran, kualitas, dan pengalaman belanja. Seperti adanya gambar produk yang jelas, diikuti dengan keterangan bahan, ukuran, keterangan model, dan rating. Dalam data lapangan terlihat bahwa informasi tersebut tidak seluruhnya dimiliki oleh brand.

Sehingga sebaiknya dibuat sebuah standarisasi agar tampilan dan menu informasi yang disajikan seluruh brand pakaian memuat informasi yang sama. Dalam rekomendasi desain hal ini dapat didukung dengan user interface yang tepat guna sesuai dengan target market. Konsumen juga akan lebih mudah dalam mengingat dan mencari informasi bila ada standarisasi. Seperti ketika akan membeli barang elektronik, seluruh spek ditampilkan dengan jelas dan rata.

Dalam penjualan sebuah produk secara online, yang perlu diperhatikan tidak melulu soal kualitas dari sebuah produk. Bila produk yang dijual sudah baik, kemudian tempat menjual dan cara menjualnyapun menentukan minat belanja konsumen. Dari sisi produk, desainer brand pakaian wanita plus-size harus memperhatikan bagian-bagian pada tubuh yang membedakan dengan wanita regular. Seperti halnya bagian yang cepat menipis atau robek, ilusi optik yang dapat memainkan siluet dari si pemakai, dan kombinasi warna. 
Wardhani

Kajian Minat Belanja Online Pakaian Ready To Wear Wanita Plus-Size

Hal tersebut dapat dilakukan dengan dua pendekatan seperti desain yang disesuaikan dengan bentuk tubuh dan melalui pola.

Dari segi tampilan platform penjualan untuk mendapatkan kualitas pengalaman belanja yang optimal diperlukan sebuah user interface yang disesuaikan dengan target market.

Rata-rata target market dari ke empat brand pada penelitian ini adalah usia 20 hingga 35 tahun. Sedangkan responden terbanyak ada juga usia 50 tahun ke atas. Sehingga ada peluang yang bisa diambil disini. Edukasi pada konsumen adalah pendekatan yang bisa dilakukan oleh sebuah brand disamping memiliki platform penjualan yang menarik. Edukasi seperti adanya pengenalan bahan pakaian yang dipakai, bukan sekedar penamaan saja, serta edukasi mengenai bentuk tubuh.

Dalam berbelanja online, konsumen di luar pulau Jawa masih kesulitan dalam hal ongkos kirim yang mahal. Jadi dengan adanya upaya dalam meningkatkan kesamaan produk yang diterima dengan apa yang dilihat pada layar, setidaknya konsumen tidak akan dikecewakan.

Sulawesi adalah wilayah yang memiliki tingkat obesitas yang tinggi menurut Riskesdas, namun banyak wilayah di luar pulau Jawa yang baru saja "melek" belanja online. Penelitian ini dapat membantu para desainer lokal terutama yang tertarik kepada pasar plus-size.

\section{DAFTAR PUSTAKA}

\section{Buku}

Ashdown, S.P (2007). Developing effective sizing systems for ready-to-wear clothing. CRC Press LLC, Woodhead Publishing Limited: USA

Fischer, Anette. (2009). Basic Fashion Design: 3, Construction. Ava Publishing. Lausanne, Switzerland

Kotler, P. (2000) Marketing Management: The Millennium Edition. Person Prentice Hall, Upper Saddle River

Lennartz, S \& Friedman, v (ed) (2009). The Smashing Book: User Interface Design in Modern Web Applications. Germany: Smashing Media $\mathrm{GmbH}$

Lupiyaodi, R. \& Hamdani, A. (2006) Manajemen Pemasaran Jasa. Jakarta: CV Alfabeta

Perera, L.N. (1974). The population of Sri Lanka. Colombo: C.I.C.R.E.D

Mowen, J., \& Minor, S. (2001). Consumer behavior. Englewood.

Sandhusen, Richard (2008). Marketing. Hauppauge, N.Y: Barron's Educational Series

Sarwono, J. \& Narimawati, U. (2015). Membuat skripsi, tesis, dan disertasi dengan SEM. Yogyakarta: Andi

Setiadi, N.J (2019). Perilaku Konsumen; Perspektif Kontemporer pada Motif, Tujuan, dan Keinginan Konsumen (Edisi ke tiga). Jakarta: Prenadamedia Gorup

SNI 0641 (2013). Tekstil - Kain Tenun - Ukuran blus dewasa. Badan Standarisasi Nasional ICS 61.020 
Sugiyono. (2013). Statistika untuk Penelitian. Bandung: Alfabeta

Surachman (2008). Dasar-Dasar Manajemen Merek. Bayumedia. Malang

Sumarwan, U. (2011). Perilaku Konsumen: Teori dan Penerapannya Dalam Pemasaran. Jakarta: PT Ghalia Indonesia

\section{Tesis \& Prosiding}

Akhtar, Inaam M.D. (2016). Research Design. Research in Social Science: Interdisciplinary Perspectives: New Delhi

Iskandar, I.A.W \& Nursari, F (2017). Perancangan Busana Muslim Ready-to-Wear untuk Perempuan Plus Size dalam Studi Kasus Brand Valisha. E-Proceeding Art \& Design, 4 (3)

Nkambule, M.T. (2010). Apparel sizing and fit preferences and problems of plus-size Swazi working women. Thesis Program Magister, University of Pretoria

Seram, N \& Kumarasiri, K (2020). Are customers satisfied? Study of the problems currently prevailing in the plus size women's wear market in Sri Lanka. Research Journal of Textile and Apparel

Wang, M. (2007). The US Plus-size Female Consumer: Self-Perception, Clothing Involvement, and the Importance of Store Attributes (Doctoral dissertation, University of North Carolina at Greensboro).
Jurnal

Alexander, Marina. (2005). Clothing fit preferences of young female adult consumers. International Journal of Clothing Science and Technology, 17(1), 52-64

Azwar, Azrul. (2004). Tubuh sehat ideal dari segi kesehatan. Seminar Kesehatan Obesitas

Baumgartner, E., Bell, P., Brophy, S. (2002). Design-Based Research: An Emerging Paradigm for Educational Inquiry. Spencer Foundation to Christopher Hoadley at Pennsylvania State University

Bastardot, F., Marques-Vidal, P., \& Vollenweider, P. (2018). Association of body temperature with obesity. The CoLaus study. International Journal of Obesity. doi:10.1038/s41366-018-0218-7

Bray, G. (1998). What is the ideal body weight? The Journal of Nutritional Biochemistry, 9(9), 489-492

Blair-Early, Adream \& Zender, Mike. (2008). User Interface Design Principles for Interaction Design. Design Issues. 24. 85-107. 10.1162/desi.2008.24.3.85.

Bye, E., LaBat, K., McKinney, E., \& Kim, D. (2008). Optimized pattern grading. International Journal of Clothing Science and Technology, 20(2), 79-92

Chandrasekar, K \& Madhavan, M. (2015). Consumer buying behavior - an overview of theory and models. St. 
Theresa Journal of Humanities and Social Sciences, 1(1), 74-112

Chowdhary, U, Beale, N.V (1988). Plus Size Women's Clothing Insterest, Satisfactions, and Dissatisfactions with Ready to Wear Apparel. Perceptual and Motor Skills, 66 (783-788)

Christel, D.A \& Dunn, S.C (2016): Average American women's clothing size: comparing National Health and Nutritional Examination Surveys (1988-2010) to ASTM International Misses \& Women's Plus Size clothing. International Journal of Fashion Design, Technology and Education

Christel, D. A. (2017). Fat fashion: Fattening pedagogy in apparel design. Fat Studies, 7(1), 44-55.

Colls, R. (2004) 'Looking alright, feeling alright: emotions, sizing and the geographies of women's experiences of clothing consumption', Social and Cultural Geography, vol.5 (4), pp.583-596.

Delone, William H., \& Ephraim R. Mclean (2004). Measureing e-commerse success: applying the DeLone \& McLean information system success model. International Journal of Electronic Commerse 9.1, 31-47

Dipoprasetyo, Ibnu. (2016). Analisis network planning dengan critical path method (CPM) dalam usaha efisiensi waktu produksi pakaian batik pada butik "omahkoe batik" di Samarinda. eJournal
Administrasi Bisnis, 4(4), 1002 - 1015

Fahmi, M, Prayogi, M. A., Jufrizen. (2018). Peran kepercayaan pelanggan dalam memediasi pengaruh kualitas website terhadap loyalitas pelanggan online shop. Jurnal Riset Sains Manajemen, 2(3), 121-130.DOI: 10.5281/ zenodo.1477534

Gribbin, E. A. (2014). Body shape and its influence on apparel size and consumer choices. Designing Apparel for Consumers, 3-16. doi:10.1533/9781782422150.1.3

Hassan, S. H., \& Harun, H. (2016). Factors influencing fashion consciousness in hijab fashion consumption among hijabistas. Journal of Islamic Marketing, 7(4), 476-494. doi:10.1108/jima-102014-0064

Haswell, N.S (2010). Analysis and Conceptualization of Plus-Size Fashion Online Shopping Motivations. The University of Machester, 35-36.

Herjanto, Eddy. (2007). Analisis perkembangan SNI bidang tekstil dan produk tekstil. Jurnal standarisasi 9(3), 116 - 122

Hidayati, S. C., Hsu, C.-C., Chang, Y.-T., Hua, K.-L., Fu, J., \& Cheng, W.-H. (2018). What Dress Fits Me Best? 2018 ACM Multimedia Conference on Multimedia Conference - MM '18. doi:10.1145/3240508.3240546

Howarton, R., \& Lee, B. (2010). Market analysis of fit preferences of female boomers. Journal of Fashion Marketing and 
Management: An International Journal, 14(2), 219-229

Hu, F. B. (2003) 'Overweight and obesity in women: health risks and consequence', Journal of Women's Health and Gender-Based Medicine, vol. 12 (2), pp.163-172.

Jongsuk Chun-Yoon, Cyntia R. Jasper (1996). Key dimensions of women's ready-towear apparel: developing a consumer size-labeling system. Dal Housie University, 14 (1), 94

Karnadjaja, Claudia Cindy Dkk. 2017. Pengaruh Persepsi Risiko, Manfaat, Dan Kemudahan Penggunaan Terhadap Minat Belanja Online Melalui Kepercayaan Dan Sikap Pada Konsumen Zalora Di Surabaya: Kajian IImiah Mahasiswa Manajemen (Kamma), 6,(2)

Limatius, H. (2018). In Search of Meaning; literary, linguistic, and translational approaches to communication. University of Tampere, 12-38

Lim, J.Y., Osman, A.B., dan Halim, M.S.B.A., 2014, Perceived Usefulness and Trust towards Consumer Behaviors: A Perspective of Consumer Online Shopping, Journal of AsianScientific Research, Vol. 4, No. 10, pp 541-546.

Mahardika, A. A. Saino, 2014, Analisis Faktor yang Mempengaruhi Niat Beli di Zalora Online Shop. Jurnal IImu Manajemen, 2(3), 917-927.
Marlock, S.., Schenk, A.., Klepser, A.., Loercher, C. (2020). Sizing and fit for plus-size men and women wear. Anthopometry, apparel, and design, 14, 371-406

Mudjijono (2016). Lancor hingga mata keteran (Motif Batik Madura). Jantra, Vol. 11 (2), 169-179

Ogden CL, Carroll MD, Kit BK, Flegal KM. Prevalence of childhood and adult obesity in the United States, 20112012. JAMA 311(8):806-14. 2014.

Sandjaja, Sudikno (2005). Prevalensi Gizi Lebih dan Obesitas Penduduk Dewasa di Indonesia. Gizi Indon, 31

Sartika, R (2011). Faktor Risiko Obesitas pada Anak 5-15 Tahun di Indonesia. Makara, Kesehatan, 15(1), 37-43

Selfia Sentana, .... (2019). Analisis FaktorFaktor yang Mempengaruhi "Body Image Satisfaction" dan Niat Beli Perempuan Millenial. Jurnal Bisnis Dan Kewirausahaan, 15(1), 1-12. doi:10.31940/jbk.v15i1.1225

Siagian, H., \& Cahyono, E. (2014). Analisis website quality, trust, dan loyalty pelanggan online shop. Jurnal Manajemen Pemasaran,8(2), 55-61

Sidharta, I \& Suzanto, B (2015). Pengaruh Kepuasan Transaksi Online Shopping dan Kepercayaan Konsumen Terhadap Sikap Serta Perilaku Konsumen Pada E-Commerse. Jurnal Computech \& Bisnis, 9(1), 23-36

Singh, D. (2006), "An evolutionary theory of 
female physical attractiveness", Eye on Psi Chi Magazine, Vol. 10 No. 3, pp. 2831.

Siregar, Nurhamida S. (2014). Karbohidrat. Jurnal IImu Keolahragaan, 13(2), 38-44

Tokatli, N. (2007). Global sourcing: insights from the global clothing industry the case of Zara, a fast fashion retailer. Journal of Economic Geography, 8(1), 21-38. doi:10.1093/jeg/lbm035

Vaccaro, K \& Shivakumar, S \& Ding, Ziqiao \& Karahalios, Karrie \& Kumar, Ranjitha. (2016). The Elements of Fashion Style. 777-785. 10.1145/2984511.2984573

Young, M. (2005) 'One Size Fits All: Disrupting the consumerized, pathologized, fat female form', in Moorti, S. and Ross, R. (Eds.) 'Commentary and Criticism', Feminist Media Studies, vol. 5 (2).

Xia, S., \& Istook, C. (2017). A Method to Create Body Sizing Systems. Clothing and Textiles Research Journal, 35(4), 235248. doi: $10.1177 / 0887302 \times 17713298$

\section{Website}

Ariyanti, F (2019). Hasil survei: 95 juta netizen RI belum pernah belanja online. Diakses pada https://www.cermati.com/artikel/ sedih-hasil-survei-95-juta-netizen-ribelum-pernah-belanja-online pada 16 Mei 2021

Johnson, O. (2020). 33 nutritional tips for 5 different body types. Diakses pada https://www.topsecretsofbeauty. com/33-nutritional-tips-for-5-differentbody-types/ pada tanggal 30 Desember 2020 pukul 10.

P2ptm.kemenkes.go.id. (2020, 14 Juni). Proporsi obesitas pada dewasa menurut provinsi 2018. Diakses pada tanggal 14 Juni, dari kemkes.go.id/resources/download/ info-terkini/hasil-riskesdas-2018

Statista.com. (2020). Indonesia e-commerce revenue. Diakses pada statista.com/outlook/243/120/ ecommerce/Indonesia\#market-arpu, pada 20 April 2020 